\title{
Histone 3 lysine 4 monomethylation supports activation of transcription in S. cerevisiae during nutrient stress
}

\author{
Neha Deshpande ${ }^{1}$ (D) $\cdot$ Rachel Jordan $^{1,2} \cdot$ Michelle Henderson Pozzi $^{1} \cdot$ Mary Bryk $^{1}$ (D)
}

Received: 15 June 2021 / Revised: 17 December 2021 / Accepted: 31 December 2021 / Published online: 18 January 2022

(c) The Author(s) 2022

\begin{abstract}
Mono-methylation of the fourth lysine on the $\mathrm{N}$-terminal tail of histone $\mathrm{H} 3$ was found to support the induction of RNA polymerase II transcription in S. cerevisiae during nutrient stress. In S. cerevisiae, the mono-, di- and tri-methylation of lysine 4 on histone $\mathrm{H} 3$ (H3K4) is catalyzed by the protein methyltransferase, Set1. The three distinct methyl marks on H3K4 act in discrete ways to regulate transcription. Nucleosomes enriched with tri-methylated H3K4 are usually associated with active transcription whereas di-methylated H3K4 is associated with gene repression. Mono-methylated H3K4 has been shown to repress gene expression in S. cerevisiae and is detected at enhancers and promoters in eukaryotes. S. cerevisiae set $1 \Delta$ mutants unable to methylate $\mathrm{H} 3 \mathrm{~K} 4$ exhibit growth defects during histidine starvation. The growth defects are rescued by either a wild-type allele of SETI or partial-function alleles of set1, including a mutant that predominantly generates H3K4me1 and not H3K4me3. Rescue of the growth defect is associated with induction of the HIS3 gene. Growth defects observed when set $1 \Delta$ cultures were starved for isoleucine and valine were also rescued by wild-type SET1 or partial-function set1 alleles. The results show that $\mathrm{H} 3 \mathrm{~K} 4 \mathrm{me} 1$, in the absence of $\mathrm{H} 3 \mathrm{~K} 4 \mathrm{me} 3$, supports transcription of the HIS3 gene and expression of one or more of the genes required for biosynthesis of isoleucine and valine during nutrient stress. Set1-like methyltransferases are evolutionarily conserved, and research has linked their functions to developmental gene regulation and several cancers in higher eukaryotes. Identification of mechanisms of H3K4me1-mediated activation of transcription in budding yeast will provide insight into gene regulation in all eukaryotes.
\end{abstract}

Keywords Histone H3 · Chromatin · Methyltransferase · H3K4me1

Abbreviations
$\begin{array}{ll}\text { H3K4 } & \text { Histone H3 lysine 4 } \\ \text { H3K4me1 } & \text { K4-monomethylated histone H3 } \\ \text { H3K4me2 } & \text { K4-dimethylated histone H3 } \\ \text { H3K4me3 } & \text { K4-trimethylated histone H3 } \\ \text { HAT } & \text { Histone acetyltransferase } \\ \text { ORFs } & \text { Open reading frames } \\ \text { 3AT } & \text { 3-Amino-1,2,4-triazole }\end{array}$

Communicated by Michael Polymenis.

Mary Bryk

bryk@tamu.edu

1 Department of Biochemistry and Biophysics, Texas A\&M University, 2128 TAMU, College Station, TX 77843, USA

2 iBio, 8800 HSC Blvd, Bryan, TX 77807, USA

\section{Introduction}

Set1 is the sole H3K4 histone methyltransferase (HMTase) in S. cerevisiae that catalyzes the mono-, di- and tri-methylation of the fourth lysine on the amino terminal tail of histone H3 (Briggs et al. 2001; Qu et al. 2018; Shilatifard 2012). Two amino acid substitution mutants of set 1 that encode partial-function H3K4 HMTases, set1-G951A, which predominantly mono-methylates $\mathrm{H} 3 \mathrm{~K} 4$, and set $1-R 1013 H$ that mono- and di-methylates $\mathrm{H} 3 \mathrm{~K} 4$, were studied to learn about the roles of individual H3K4 methyl marks in transcription by RNA polymerase II in S. cerevisiae (Fig. 1). The SET family of H3K4 histone methyltransferases is conserved in eukaryotes (Miller et al. 2001; Takahashi et al. 2011). Mutations in Set1-like H3K4 HMTases alter segmentation in Drosophila melanogaster and floral development in Arabidopsis thaliana (Breen 1999; Jiang et al. 2011; Shilatifard 2012). Human homologs of Set1, including MLL1 and its translocation alleles, are implicated in hematological malignancies, such as mixed lineage leukemia, acute myeloid 


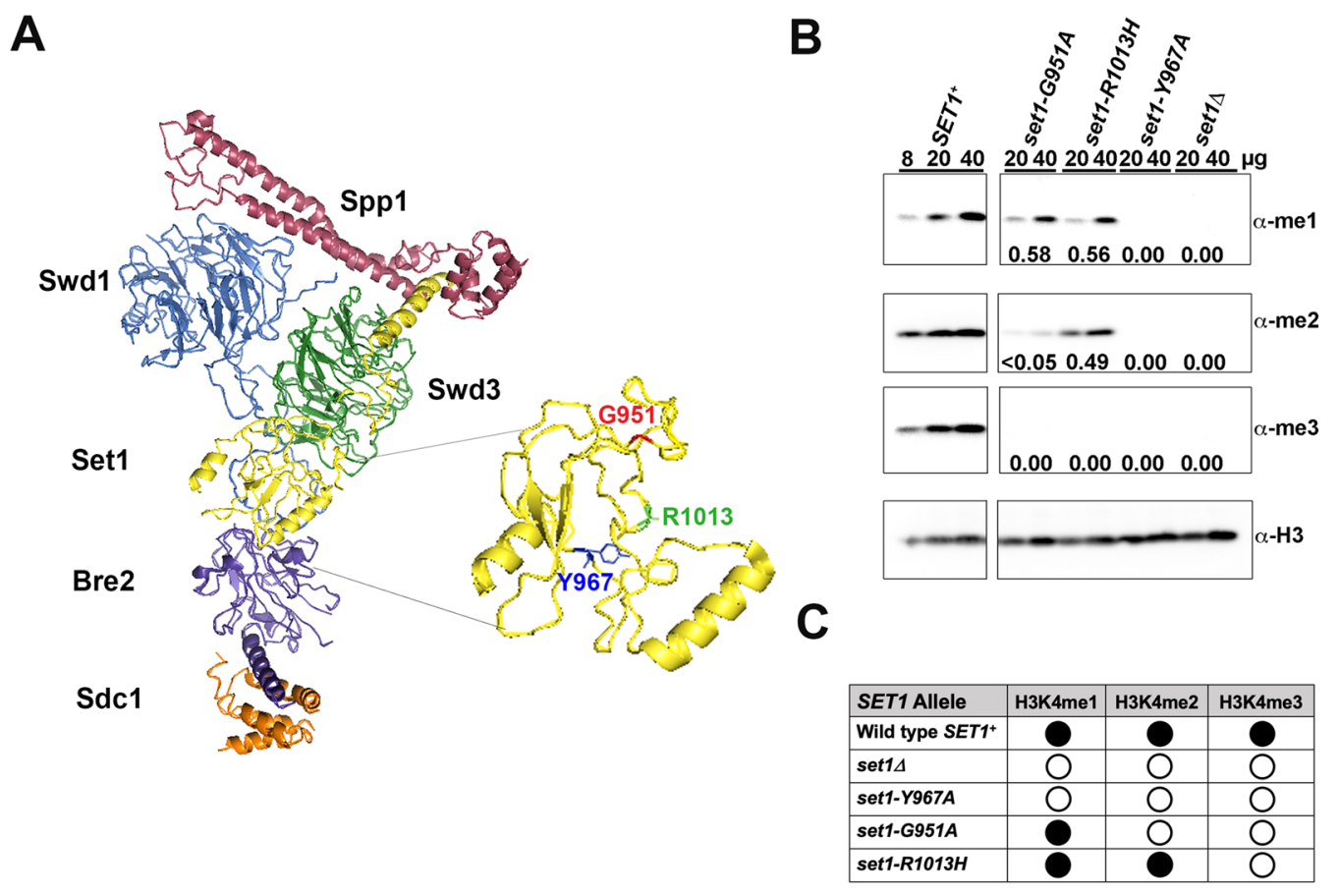

Fig. 1 Location and methylation activity of Set1 mutants. A CryoEM structure of $S$. cerevisiae Set1 in the COMPASS complex (Qu et al. 2018). COMPASS proteins, Bre2 (purple), Sdc1 (orange), Set1 (yellow), Spp1 (magenta), Swd1 (blue), and Swd3 (green) are shown (Krogan et al. 2002; Miller et al. 2001; Nagy et al. 2002; Roguev et al. 2001; Takahashi et al. 2011). The C-terminal tail of Swd1 weaves within the complex to provide a central scaffold for assembly of COMPASS (Qu et al. 2018; Takahashi et al. 2011). The Swd2 protein (not shown) connects Swd1 and Swd3 to the $\mathrm{N}$ terminus of Set1 (Wang et al. 2018) and interacts with the CTD of RNA Pol II allowing COMPASS to move along DNA sequences during Pol II transcription (Bae et al. 2020). Inset, substitution of three amino acid (G951, Y967, and R1013) in or near the Set1 active site generated set1 mutants with different methylation abilities (Williamson et al. 2013). B Representative Western blot measuring in vivo steady-state

leukemia and acute lymphoblastic leukemia (Kandoth et al. 2013; Roguev et al. 2001; Ruault et al. 2002; Shilatifard 2012; Slany 2009). The importance of Set1 family proteins in biological processes from yeast to humans underscores their importance in gene regulation (Cenik and Shilatifard 2021).

The structural organization of eukaryotic DNA into chromatin regulates transcription by RNA polymerases (Han and Grunstein 1988; Izban and Luse 1992; Kornberg and Thonmas 1974; Wasylyk and Chambon 1979; Workman and Kingston 1998). To overcome the physical barrier imposed by chromatin, RNA polymerases rely on transacting proteins and protein complexes, including chromatin remodelers, transcription factors, co-activators and histonemodifying enzymes to make DNA sequences in chromatin accessible to RNA polymerase II (Castillo et al. 2017; Chatterjee et al. 2011; Côté et al. 1998; Lee et al. 1993, 2007; levels of H3K4me1 ( $\alpha$-me1), H3K4me2 ( $\alpha$-me2), and H3K4me3 $(\alpha-m e 3)$ in whole cell extracts from the yeast strains indicated above the blot image $(n=3)$. The level of total histone H3 $(\alpha-\mathrm{H} 3)$ was used to normalize the amount of extract loaded in each lane. Numbers indicate the normalized levels of $\mathrm{H} 3 \mathrm{~K} 4 \mathrm{me} 1 / 2 / 3$ detected in the mutants relative to the wild-type $S E T 1^{+}$strain. Bands labeled 0 (no signal) or $>0.05 \%$ (low signal, yet visible by eye) were not detected above background by the Imagequant TL 8.1 image detection software. The samples shown were separated on the same gel and analyzed on the same membranes. Samples between the $S E T 1^{+}$and set1-G951A samples were cropped out of the figure. C Summary of the H3K4 methylation activity in wild-type SET1 and set1 mutants, a filled circle indicates methylation is detectable above background; open circle, methylation is not detected by Imagequant TL 8.1 image detection software (see "Materials and methods")

Santos-Rosa et al. 2003). Methylation of histones by histone methyltransferases regulates transcription by RNA polymerase II (Hyun et al. 2017).

Saccharomyces cerevisiae Set 1 is a member of the Complex Associated with Set1, COMPASS (Fig. 1) (Bae et al. 2020; Briggs et al. 2001; Miller et al. 2001; Morillon et al. 2005; Mueller et al. 2006; Roguev et al. 2001). The effect of H3K4 methylation on the accessibility of chromatin depends on the chromatin context, consistent with published work showing that H3K4 mono-, di-, and tri-methylation have different effects on gene transcription (Kusch 2012; Pokholok et al. 2005). Chromatin immunoprecipitation (ChIP) and ChIP-seq experiments revealed that the distribution of H3K4me1, H3K4me2 and H3K4me3 across open reading frames is not identical (Bernstein et al. 2005; Pokholok et al. 2005; Soares et al. 2017; Weiner et al. 2012). For the most highly expressed genes in $S$. cerevisiae, nucleosomes with 
H3K4me3 peak at the promoter and up to 200 bp beyond the transcription start site, nucleosomes with $\mathrm{H} 3 \mathrm{~K} 4 \mathrm{me} 2$ are enriched in the middle of the ORF, and nucleosomes with H3K4me1 are found at relatively low levels across an ORF. In some cases, the distributions of H3K4 methylated histones have provided insight into their functions.

Methylation of histones on its own has not been shown to change the structure of chromatin, instead methylated histones may act by recruiting effector proteins to chromatin (Cheng et al. 2014; Musselman et al. 2012; Pray-Grant et al. 2005; Taverna et al. 2006). H3K4me3 is usually associated with active transcription (Kusch 2012; Ng et al. 2003; Schneider et al. 2005), which is supported by work showing that $\mathrm{H} 3 \mathrm{~K} 4 \mathrm{me} 3$ is recognized by the chromodomain-containing protein, Chd1, a member of the SAGA transcription coactivator complex (Pray-Grant et al. 2005). The transcription factor TAF3 also interacts with $\mathrm{H} 3 \mathrm{~K} 4 \mathrm{me} 3$ to recruit $\mathrm{TF}_{\mathrm{II}} \mathrm{D}$ to promoters (Vermeulen et al. 2007). In S. cerevisiae, the chromatin remodeler Isw 1 interacts with methylated $\mathrm{H} 3 \mathrm{~K} 4$ to generate accessible chromatin at the $5^{\prime}$ end of the MET16 gene (Santos-Rosa et al. 2003). H3K4me3 is also recognized by other protein complexes, some of which are negative effectors of transcription (Musselman et al. 2012). In response to DNA damage, the PHD domain of ING2 (INhibitor of Growth 2), a subunit of the mSin3a-HDAC1 histone deacetylase complex, binds to H3K4me3, stabilizing $\mathrm{mSin} 3 \mathrm{a}-\mathrm{HDAC} 1$ at the promoter of cyclin $\mathrm{D} 1$ gene and other proliferation genes, leading to repression of transcription (Shi et al. 2006). H3K4me2 is associated with repression of transcription and has been shown to interact with histone deacetylases that deacetylate histones at the $5^{\prime}$ ends of some highly expressed genes (Kim and Buratowski 2009; Pinskaya and Morillon 2009).

Progress is being made toward understanding the roles $\mathrm{H} 3 \mathrm{~K} 4 \mathrm{me} 1$ plays in gene regulation. In yeast, the absence or presence of $\mathrm{H} 3 \mathrm{~K} 4 \mathrm{me} 1$ at osmostress-responsive gene determines whether RSC or SWR-C remodels chromatin at the promoters (Nadal-Ribelles et al. 2015). In higher eukaryotes, nucleosomes with $\mathrm{H} 3 \mathrm{~K} 4 \mathrm{me} 1$ are enriched at enhancer elements and the function of $\mathrm{H} 3 \mathrm{~K} 4 \mathrm{me} 1$ at enhancers is a topic of intense research (Calo and Wysocka 2013; Catarino and Stark 2018; Froimchuk et al. 2017). Recent work using human and mouse germ cells and ESCs showed that the patterns of $\mathrm{H} 3 \mathrm{~K} 4 \mathrm{me} 1, \mathrm{H} 3 \mathrm{~K} 4 \mathrm{me} 3$ and $\mathrm{H} 3 \mathrm{~K} 27 \mathrm{me} 3$ at promoters specify the potential transcriptional state of a promoter (Bae and Lesch 2020). The ability to tease apart the roles of individual H3K4 methyl marks will lead to better understanding of the role of $\mathrm{H} 3 \mathrm{~K} 4 \mathrm{me} 1$ in gene expression.

Because Set1 is the only H3K4 HMTase in S. cerevisiae, it is an excellent system to study the effect of the three H3K4 methyl marks on transcription. In a previous study, mutants of SET1 were made that encode proteins with amino acid substitutions in the SET domain of Set1 (Fig. 1)
(Williamson et al. 2013). Amino acid substitution mutants were constructed to alter residues near and in the active site of Set1 to generate mutants with different H3K4 methylation capabilities. Yeast strains expressing the set1-Y967A allele are indistinguishable from a set $1 \Delta$ mutant with respect to methylation of $\mathrm{H} 3 \mathrm{~K} 4$. The set1-G951A mutant produces predominantly $\mathrm{H} 3 \mathrm{~K} 4 \mathrm{me} 1$ with low levels of $\mathrm{H} 3 \mathrm{~K} 4 \mathrm{me} 2$. The residue G951 is highly conserved in Set1 family proteins and is important for Set1 function (Dillon et al. 2005; Lee et al. 2018; Nislow et al. 1997; Sollier et al. 2004). A second partial-function mutant, set $1-R 1013 \mathrm{H}$, generates H3K4me 1 and $\mathrm{H} 3 \mathrm{~K} 4 \mathrm{me} 2$ in vivo (Fig. 1).

In this study, setl partial-function mutants were studied to learn about the roles of individual H3K4 methyl marks in RNA polymerase II transcription in S. cerevisiae. Two amino acid biosynthetic pathways, the histidine and isoleucine-valine pathways, were used to study the roles of individual H3K4 methyl marks in transcription when cells are starved for amino acids. The results show that induction of the HIS 3 gene occurs in the absence of $\mathrm{H} 3 \mathrm{~K} 4 \mathrm{me} 2$ and $\mathrm{H} 3 \mathrm{~K} 4 \mathrm{me} 3$, indicating that $\mathrm{H} 3 \mathrm{~K} 4 \mathrm{me} 1$ supports induction of the HIS3 gene under histidine-starvation conditions. In addition, the results suggest that one or more genes required for biosynthesis of isoleucine and valine (Falco and Dumas 1985; Falco et al. 1985) is activated in the presence of H3K4me 1 when H3K4me3 and H3K4me2 are absent. The major finding is that $\mathrm{H} 3 \mathrm{~K} 4 \mathrm{me} 1$ supports induction of transcription in $S$. cerevisiae cultures grown under amino-acid starvation conditions.

\section{Materials and methods}

\section{Media}

Standard media preparation protocols were used (Rose et al. 1990). YPADTU is YPD media supplemented with $40 \mathrm{mg} / \mathrm{L}$ adenine hemisulfate, $80 \mathrm{mg} / \mathrm{L}$ L-tryptophan and $20 \mathrm{mg} / \mathrm{L}$ uracil. Where indicated, $1 \mathrm{M}$ 3-amino-1,2,4-triazole (3AT) made in sterile $\mathrm{H}_{2} \mathrm{O}$ was added to media to a final concentration of $10 \mathrm{mM}$. Sulfometuron Methyl (SMM), made in dimethyl sulfoxide (DMSO), was added to media to a final concentration of $1 \mu \mathrm{g} / \mathrm{mL}$. SC Complete is defined synthetic medium containing all nutrients required for yeast cell growth. SC-His, SC-Ile Val and SC-Trp are synthetic complete yeast growth media lacking histidine, isoleucine and valine, or tryptophan, respectively.

\section{Yeast strains}

Saccharomyces cerevisiae strains used in this study are listed in Supplementary Table 1. Yeast strains were made by standard genetic crosses and genetic transformation. The initial characterization of mutant alleles of SETI was described 
previously (Williamson et al. 2013). Cloned $\mathrm{SETI}^{+}$or set 1 mutant genes in StuI-linearized pRS406 plasmids were integrated into the ura3-52 locus of MBY1590 and MBY3078 to make the SET1 ${ }^{+}$(MBY2994 and MBY3148, respectively), set1-Y967A (MBY2998 and MBY3152, respectively), and set1-R1013H (MBY2996 and MBY3181, respectively) strains (Sikorski and Hieter 1989). The cloned set1-G951A gene in a StuI-linearized pRS406 plasmid was integrated into the ura3-52 locus of MBY3078 to make MBY3154. A StuIlinearized pRS406 plasmid with no insert was integrated into the ura3-52 locus of MBY1590 to make MBY2992 and into the ura3-52 locus of MBY3078 to make MBY3149.

Plasmids containing HHT2-HHF2 and hht2-K4R-HHF2 have been described previously (Briggs et al. 2001). The genes encoding HHT2 and HHF2 or hht2-K4R-HHF2 were cloned into pRS414 plasmids that carry a TRP1 selectable marker (Sikorski and Hieter 1989). The endogenous S. cerevisiae HHT1-HHF1 and HHT2-HHF2 genes encoding histones $\mathrm{H} 3$ and $\mathrm{H} 4$ were deleted and replaced with selectable marker genes. The resulting yeast strains expressed either the wild-type HHT2-HHF2 genes (pHHT2-HHF2 TRP1 $C E N$, MBY3029) or a mutant version of HHT2 (hht2$H 3 K 4 R$ ) with a wild-type $H H F 2$ gene (phht2-K4R-HHF2 TRP1 CEN, MBY3030). Cloned SET1 ${ }^{+}$or set1 mutant genes in $S t u I$-linearized pRS406 plasmids were integrated into the ura3-52 locus of MBY3029 to make the $\mathrm{SETI}^{+}$(MBY3031), set1-G951A (MBY3242), set1-Y967A (MBY3033), or set1R1013H (MBY3035) strains. A StuI-linearized pRS406 plasmid with no insert was integrated into the ura3-52 locus of MBY3029 to make the set14 strain (MBY3032). The $S t u I$-linearized plasmids were also transformed into MBY3030 (with phht2-K4R-HHF2 genes) to make the SET1 $^{+}$(MBY3037), set1-G951A (MBY3243), set1-Y967A (MBY3039), set1-R1013H (MBY3041) and the set1A (MBY3038) strains.

\section{Molecular rendering of COMPASS}

The structure of the COMPASS complex from PDB: 6BX3 (Qu et al. 2018) was modified using PyMOL (v.1.7.4.5 Schrodinger (2015)) to highlight modified amino acid residues in the Set1 protein (Fig. 1).

\section{Growth assays}

Cultures were grown to saturation at $30{ }^{\circ} \mathrm{C}$ in $\mathrm{SC}$-His or YPADTU liquid medium. Eight, five-fold serial dilutions were made in sterile water. The last six dilutions were plated $(5 \mu \mathrm{l})$ on each of four types of solid agar plates: SC-His, SCHis $+10 \mathrm{mM} 3 \mathrm{AT}$, SC-complete, and SC-complete $+10 \mathrm{mM}$ 3AT. Plates were imaged after 24 and $42-44 \mathrm{~h}$ of incubation at $30{ }^{\circ} \mathrm{C}$. For experiments with yeast strains expressing histone $\mathrm{H} 3 \mathrm{~K} 4$ or H3K4R from plasmids, six ten-fold serial dilutions were made in sterile water and dilutions were plated, as described above. Plates were incubated at $30{ }^{\circ} \mathrm{C}$ and imaged after $42 \mathrm{~h}$. For Ile Val starvation growth assays, eight, five-fold serial dilutions were made in sterile water using overnight cultures grown in YPADTU. The last six dilutions were plated $(5 \mu \mathrm{l})$ on solid agar plates: SC-Ile Val + DMSO, SC-Ile Val + $1 \mu \mathrm{g} / \mathrm{mL}$ SMM, SC-complete + DMSO, and SC-complete $+1 \mu \mathrm{g} / \mathrm{mL}$ SMM. Plates were imaged after $72-96 \mathrm{~h}$ of incubation at $30{ }^{\circ} \mathrm{C}$.

\section{RNA isolation and northern blotting}

Saturated cultures of yeast strains grown in SC-His liquid medium were diluted into $50 \mathrm{~mL}$ of fresh $\mathrm{SC}$-His medium at $\sim 4 \times 10^{6}$ cells $/ \mathrm{mL}$ and grown to a density of $1-2 \times 10^{7}$ cells $/ \mathrm{mL}$ at $30^{\circ} \mathrm{C}$ in a shaker incubator. After $4 \mathrm{~h}, 500 \mu \mathrm{L}$ of $1 \mathrm{M}$ 3AT (final concentration $10 \mathrm{mM}$ ) or sterile distilled water were added to the cultures, which were incubated at $30^{\circ} \mathrm{C}$ in a shaker incubator for one hour. Total RNA was extracted from yeast cultures, as previously described (Schmitt et al. 1990) with the following modifications. Cells were re-suspended in $450 \mu \mathrm{l} \mathrm{AE}$ buffer $\left(50 \mathrm{mM} \mathrm{C}_{2} \mathrm{H}_{3} \mathrm{NaO}_{2}\right.$ pH 5.3, $10 \mathrm{mM}$ EDTA), and then transferred to a microfuge tube to which $50 \mu 110 \%$ SDS was added. Extraction with an equal volume of chloroform:isoamyl alcohol (24:1) was performed before the addition of $50 \mu \mathrm{L} 3 \mathrm{M}$ sodium acetate pH 5.3 and 2.5 volumes $100 \%$ ethanol. After precipitation, RNA was re-suspended in sterile milliQ $\mathrm{H}_{2} \mathrm{O}$ and stored at $-70{ }^{\circ} \mathrm{C}$. RNA $(15 \mu \mathrm{g})$ was analyzed by Northern blotting, as described previously (Swanson et al. 1991). The steadystate level of HIS3 transcript was detected by hybridization with a strand-specific ${ }^{32} \mathrm{P}$-labeled riboprobe. To normalize loading of RNA samples, a ${ }^{32} \mathrm{P}$-labeled ACT1 DNA probe synthesized by random priming was used to detect the ACTI mRNA level. For the northern blots analyzing the set1G951A strain, a ${ }^{32} \mathrm{P}$-labeled HIS3 DNA probe synthesized by random priming was used to detect the HIS3 mRNA level. To analyze the Northern blots, the ratio of HIS3/ACTI mRNA was calculated for each strain grown in SC-His and SC-His $+10 \mathrm{mM}$ 3AT. To calculate the fold change of HIS 3 transcript in presence of $3 \mathrm{AT}$, the ratio of HIS3/ACTI mRNA for each strain grown in SC-His + $10 \mathrm{mM} 3 \mathrm{AT}$ was normalized to the corresponding HIS3/ACT1 transcript levels from cultures grown in SC-His.

The optimal induction of HIS3 transcript after addition of 3AT was determined using a time-course experiment (Supplementary Fig. 1). The steady-state level of HIS3 transcript was detected as described above. To normalize loading of RNA samples, a ${ }^{32} \mathrm{P}$-labeled $18 \mathrm{~S}$ ribosomal RNA riboprobe was used to detect the rRNA level. To analyze the Northern blots, the ratio of HIS3 mRNA/18S rRNA was calculated for each strain at each time point. Then, the ratio of HIS3 mRNA/18S rRNA at 5, 10, 30, 60, and 120 min post 
addition of $10 \mathrm{mM} 3 \mathrm{AT}$ was normalized to the corresponding ratio at $0 \mathrm{~min}$ (prior to adding $3 \mathrm{AT}$ ). All Northern blots were imaged using a G.E Typhoon FLA 7000 and quantified using G.E Imagequant TL 8.1 software.

\section{Whole cell protein extracts and western blotting}

Yeast whole cell protein extracts were prepared as described (Mueller et al. 2006). Proteins from clarified whole-cell extracts $(8,20$ or $40 \mu \mathrm{g})$ were separated on $10 \%$ SDS-polyacrylamide gels, transferred to PVDF membrane, and probed with $\alpha$-histone $\mathrm{H} 3$ (ab1791, Abcam; 1:1000), $\alpha$-K4-monomethyl H3 (13-0040, Epicypher, 1:2000), $\alpha$-K4-dimethyl H3 (710796, Invitrogen; 1:1000), or $\alpha$-K4trimethyl H3 (13-0041, Epicypher; 1:2000). Antibody binding was detected with HRP-conjugated $\alpha$-rabbit secondary antibodies (1706715, Biorad; 1:2000) and Clarity Western ECL substrate (Bio-Rad, Hercules, CA, USA). Western blots were imaged on an Amersham Imager 600 and quantified using Imagequant TL 8.1 software.

\section{Chromatin immunoprecipitation}

Saturated cultures of yeast strains grown in SC-His liquid medium were diluted into $200 \mathrm{~mL}$ of fresh SC-His medium at $\sim 4 \times 10^{6}$ cells $/ \mathrm{mL}$ and grown to a density of $1-2 \times 10^{7}$ cells $/ \mathrm{mL}$ at $30^{\circ} \mathrm{C}$ in a shaker incubator. After $4 \mathrm{~h}, 2 \mathrm{~mL}$ of $1 \mathrm{M}$ 3AT (final concentration $10 \mathrm{mM}$ ) or sterile distilled water was added to the cultures, which were incubated at $30^{\circ}$ $\mathrm{C}$ in a shaker incubator for $60 \mathrm{~min}$. Lysates were prepared as previously described ( $\mathrm{Li}$ et al. 2006) with the following modifications. Breakage of cells was performed in $500 \mu \mathrm{L}$ lysis buffer (50 mM HEPES/KOH pH 7.5, $140 \mathrm{mM} \mathrm{NaCl}$, $1 \mathrm{mM}$ EDTA, $1 \%$ Triton X-100, 0.1\% Sodium deoxycholate, $1 \mathrm{mM}$ PMSF, $1 \mathrm{mM}$ benzamidine, $1 \mu \mathrm{g} / \mathrm{mL}$ each leupeptin pepstatin, and bestatin) using a Mini-BeadBeater 16 (Biospec) at $4{ }^{\circ} \mathrm{C}$ with $1 \mathrm{~min}$ beating followed by $2 \mathrm{~min}$ of rest, repeated four times. Chromatin in $1 \mathrm{~mL}$ of lysis buffer was sonicated in a $4{ }^{\circ} \mathrm{C}$ water bath (Bioruptor Water Cooler, Diagenode) using a Bioruptor 300 Sonication System (Diagenode) for 300 cycles of $30 \mathrm{~s}$ on, $45 \mathrm{~s}$ off, power setting high, to shear chromatin to a length $\leq 500 \mathrm{bp}$. Sonicated chromatin was clarified by centrifugation at $13 \mathrm{~K} \mathrm{rpm}, 4{ }^{\circ} \mathrm{C}$, $30 \mathrm{~min}$. Sonicated chromatin was incubated with antibody in a total volume of $500 \mu \mathrm{L}$ for $16-18 \mathrm{~h}$ with rocking at $4{ }^{\circ} \mathrm{C}$. The following antibodies were used; $\alpha-\mathrm{H} 3$, Abcam ab1791 (4 $\mu \mathrm{g} / \mathrm{IP}$, lot \#s: GR3297884-1, GR3297878-1, GR3356864-1 and GR3366670-1), $\alpha$-H3K4me3, Epicypher 13-0041 (2 $\mu \mathrm{g} / \mathrm{IP}$, lot \#s: 20083002-42 and 20218003-49), $\alpha-H 3 K 4 m e 2$, Epicypher 13-0027 (4 $\mu \mathrm{g} / \mathrm{IP}$ lot \#: 2025200204), $\alpha$-H3K4me1, Epicypher 13-0040 (2 $\mu \mathrm{g} / \mathrm{IP}$ lot \#s: 19338001-42 and 20178005-44). IPs were processed as described previously (Bryk et al. 2002), with the following exceptions. Pierce protein A/G agarose beads were used to pull down crosslinked protein-DNA complexes (Pierce Biotechnology, Thermofisher, IL, USA). ChIP eluates were purified using the ChIP DNA clean and concentrator kit, as recommended by the manufacturer (Zymo Research Corp, CA, USA). Purified extracts eluted in $100 \mu \mathrm{L}$ elution buffer were stored at $-70{ }^{\circ} \mathrm{C}$.

\section{Analysis of ChIPs}

Quantitative polymerase chain reactions (qPCR) were performed to analyze the distribution of H3K4me1, H3K4me2, H3K4me 3 and total histone $\mathrm{H} 3$ at HIS3 promoter, 5' and 3' regions of the HIS3 ORF, the promoter of the ACTl gene, and a 284-bp intergenic region (IGR) on chromosome VIII from positions 384,624 to 384,908 . Oligonucleotides are listed in Supplementary Table 2.

To analyze the H3K4me marks in ChIP eluates, duplicate reactions using $2.5 \mu \mathrm{L}$ input DNA (1:10) and $2.5 \mu \mathrm{L}$ immuno-precipitated DNA were amplified in $10 \mu \mathrm{L}$ reactions containing $0.5 \mu \mathrm{M}$ each oligonucleotide and $1 \mathrm{X}$ homemade master mix (1X New England Biolabs (NEB) PCR buffer, $2.5 \mathrm{mM} \mathrm{MgCl}_{2}, 0.2 \mathrm{mM}$ dNTPs, $1 \mathrm{X}$ Evagreen (Biotium), and 1 unit NEB Taq). Reactions were performed in a BioRad CFX96 Real-Time System C1000 Thermal 71 Cycler. The PCR parameters were 1 cycle of $95{ }^{\circ} \mathrm{C}, 3 \mathrm{~min}$; 30 cycles of $95{ }^{\circ} \mathrm{C}$ for $30 \mathrm{~s}, 58{ }^{\circ} \mathrm{C}$ for $30 \mathrm{~s}, 72^{\circ} \mathrm{C}$ for $30 \mathrm{~s} ; 1$ cycle of $95^{\circ} \mathrm{C}$ for $30 \mathrm{~s}$ followed by melt curve analysis from $65^{\circ} \mathrm{C}$ to $95^{\circ} \mathrm{C}$ in $0.5^{\circ} \mathrm{C}$ increments for $5 \mathrm{~s}$ each. For analysis of HIS3 3' ORF, the annealing temperature was $54^{\circ} \mathrm{C}$. The threshold cycle reading was taken after each $72{ }^{\circ} \mathrm{C}$ elongation step. Percentage of DNA immuno-precipitated (\%IP) was calculated by dividing the signal from IP DNA by that of input DNA for all $\mathrm{H} 3 \mathrm{~K} 4 \mathrm{me}$ ChIPs and total histone $\mathrm{H} 3$ ChIPs from each location. The \%IP for each H3K4me mark was normalized to the \% IP of total $\mathrm{H} 3$ at each location.

\section{Statistical analysis}

Statistical analysis for the Northern blots and ChIP experiments was performed using the Mann-Whitney $U$ test (Allaire 2012) on R studio.

\section{Results}

\section{Histone H3K4 methylation by Set1 is required for robust growth of yeast cultures when grown under nutrient stress}

The positions of the amino-acid substitutions in the set 1 mutants used in this study are shown in a reproduction of the COMPASS cryo-EM structure (Qu et al. 2018) (Fig. 1A). 
The set 1 mutants generate levels of $\mathrm{H} 3 \mathrm{~K} 4 \mathrm{me} 1 / 2 / 3$ that are different from those observed in cultures expressing wildtype SET1. Western blots using whole cell extracts show that two mutants, set1 $\Delta$ and set1-Y967A, have no detectable $\mathrm{H} 3 \mathrm{~K} 4 \mathrm{me} 1 / 2 / 3$; set $1-G 951 \mathrm{~A}$ has $\mathrm{H} 3 \mathrm{~K} 4 \mathrm{me} 1$ at $58 \%$ of $\mathrm{SETI}^{+}$(WT), H3K4me2 at $<5 \%$ of WT and no detectable $\mathrm{H} 3 \mathrm{~K} 4 \mathrm{me} 3$; and set $1-\mathrm{R} 1013 \mathrm{H}$ has $\mathrm{H} 3 \mathrm{~K} 4 \mathrm{me} 1$ at $56 \%$ of WT, H3K $4 \mathrm{me} 2$ at $49 \%$ of WT, and no detectable H3K4me3 (Fig. 1B). The methylation proficiency of wild-type SETI and the set1 mutants is indicated in Fig. 1C.

Two amino acid biosynthetic pathways, the histidine and isoleucine-valine pathways, were used as models to evaluate the role of individual H3K4 methyl marks during aminoacid starvation. The HIS3 gene codes for imidazole glycerol phosphate dehydratase (Fink 1964), the enzyme that catalyzes the sixth step in the biosynthesis of histidine in S. cerevisiae. The herbicide 3-amino-1,2,4-triazole (3AT) is a competitive inhibitor of imidazole glycerol phosphate dehydratase and it is used to induce histidine-starvation. Amino acid starvation initiates the general amino acid control (GAAC) pathway in S. cerevisiae (Brennan and Struhl 1980; Hope and Struhl 1985). The HIS3 gene and most amino acid biosynthetic genes are regulated by the GAAC pathway and require the transcription regulator Gcn 4 for initiation of transcription (Hinnebusch 2005). Growth of yeast cultures in 3AT activates Gcn4, which recruits the histone acetyltransferase (HAT) Gcn5 to many promoters, including the HIS 3 promoter, initiating a cascade of events that lead to transcription of the HIS3 gene (Hill et al. 1986; Kuo and Allis 1998; Kuo et al. 2000). The GAAC pathway also controls genes required for the biosynthesis of isoleucine and valine in S. cerevisiae. Sulfometuron methyl (SMM) is a competitive inhibitor of the ILV2 gene, acetolactate synthase (Falco and Dumas 1985). In this study, SMM was used to induce starvation for isoleucine and valine to evaluate the effect of H3K4 methylation on growth of $S$. cerevisiae cultures during starvation for branched-chain amino acids.

The effects of alterations in the levels of $\mathrm{H} 3 \mathrm{~K} 4 \mathrm{me} 1 / 2 / 3$ on the growth of yeast cultures under histidine-starvation conditions were evaluated using yeast cultures expressing either wild-type SET1, set1A or one of three set1 aminoacid substitution variants on four different types of solid agar media (Fig. 2). The cultures grew similarly on SC Complete medium with the herbicide 3AT, SC Complete medium without $3 \mathrm{AT}$, and SC medium lacking histidine, SC-His (Fig. 2A, B right panel). In contrast, all cultures grew less well on SC-His + 3AT (Fig. 2B, left panel). The herbicide $3 \mathrm{AT}$ was expected to have a negative effect on growth because it causes histidine starvation when used in medium lacking histidine.

Reduced growth of the set $1 \Delta$ and set1-Y967A mutants was observed on SC-His + 3AT agar (Fig. 2B, left panel). The extent of growth of set1-G951A, set1-R1013H, or SET1 ${ }^{+}$
A

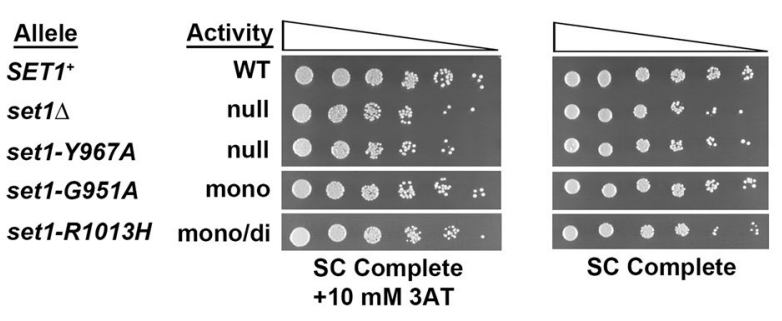

B
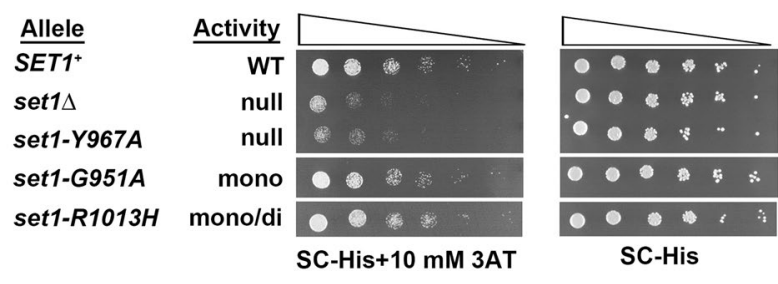

Fig. 2 Growth of mutants lacking Set1 methylation activity is sensitive to histidine starvation induced by $3 \mathrm{AT}$. Five-fold serial dilutions of yeast cultures expressing wild-type $S E T 1^{+}$or set 1 mutant alleles were spotted onto A SC-complete agar with or without $10 \mathrm{mM}$ 3AT and B SC-His agar with or without $10 \mathrm{mM}$ 3AT. Allele, relevant genotype. Activity, H3K4 methylation activity determined by Western blots (Fig. 1B); WT, H3K4me1/2/3 detected; Null, no H3K4me1/2/3 detected; mono, H3K4me1 detected with low or no H3K4me2/3; mono/di, H3K4me1/2 detected with no H3K4me3 (Fig. 1B). Dilution of the cultures, right triangle at the top of each column. Plates were incubated at $30^{\circ} \mathrm{C}$ for $42 \mathrm{~h}$ prior to imaging. All cultures shown in the figure were grown on the same plate. The images were cut to remove a strain not being considered here

yeast strains expressing partially or fully functional Set 1 proteins on SC-His + 3AT agar was similar, and all grew better than the set $1 \Delta$ and set $1-Y 967 A$ mutants. Given that the set1-G951A mutant catalyzes H3K4me1 mainly with very low levels of $\mathrm{H} 3 \mathrm{~K} 4 \mathrm{me} 2$ and undetectable $\mathrm{H} 3 \mathrm{~K} 4 \mathrm{me} 3$ (Fig. 1B), the results suggest that $\mathrm{H} 3 \mathrm{~K} 4 \mathrm{me} 2$ and $\mathrm{H} 3 \mathrm{~K} 4 \mathrm{me} 3$ are not required for wild-type levels of growth under histidine-starvation conditions.

A literature search was performed to identify other genes regulated by the GAAC pathway that might be also regulated by H3K4 methylation. The ILV genes, ILVI, ILV2, $I L V 3, I L V 5$ and $I L V 6$ and the aminotransferases BATI and $B A T 2$, encode enzymes that catalyze the biosynthesis of isoleucine and valine in $S$. cerevisiae. SMM, a competitive inhibitor of the $I L V 2$ gene, was used to evaluate the role of H3K4 methylation on growth of cultures during starvation for isoleucine and valine. Saturated cultures of yeast strains expressing wild-type SET1, set1A or set1 aminoacid substitution variants were analyzed for growth on medium with or without SMM. The growth of strains on SC Complete media + DMSO and SC Complete containing SMM was mostly similar, although the size of set $1 \Delta$ colonies on SC Complete + SMM was smaller than other strains (Fig. 3A). Growth of the five yeast strains was 
A

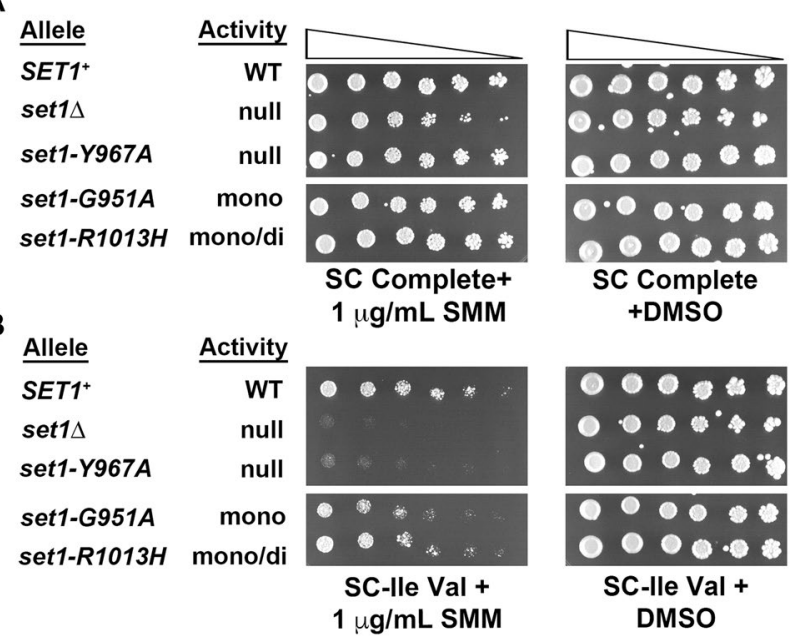

Fig. 3 Growth of mutants lacking Set1 methylation activity is sensitive to isoleucine and valine starvation induced by SMM. Five-fold serial dilutions of yeast strains expressing wild-type $S E T 1$ or mutant set1 alleles were spotted onto A SC-complete solid agar and B SCIle Val plates with $1 \mu \mathrm{g} / \mathrm{mL}$ SMM or DMSO. Plates were incubated at $30{ }^{\circ} \mathrm{C}$ for $4-5$ days prior to imaging. Other labels, as in Fig. 2. All cultures shown were grown on the same plate. The images were cut to remove a strain not being considered here

similar on synthetic medium lacking isoleucine and valine
(SC-Ile Val + DMSO, Fig. 3B, right). When compared to strains expressing wild-type $S E T 1^{+}$or the partial-function alleles of set1 (set1-G951A and set1-R1013H), the set1A and set1-Y967A mutants grew poorly on medium lacking isoleucine and valine in presence of SMM (SC-Ile Val $+1 \mu \mathrm{g}$ / mL SMM) (Fig. 3B, left). The partial-function mutant set 1G951A, which performs mainly H3K4me1, exhibited better growth than the set1A and set1-Y967A mutants suggesting that $\mathrm{H} 3 \mathrm{~K} 4 \mathrm{me} 2$ and $\mathrm{H} 3 \mathrm{~K} 4 \mathrm{me} 3$ are not required for wild-type growth under conditions of isoleucine and valine starvation.

In addition to methylation of histone $\mathrm{H} 3$, Set 1 methylates the Dam 1 protein that functions in chromosome segregation in S. cerevisiae (Latham et al. 2011; Zhang et al. 2005). To verify that the growth phenotypes observed in Figs. 2 and 3 were due to changes in methylation of histone $\mathrm{H} 3$ and not another target of Set1, SETI ${ }^{+}$and set1 mutant alleles were transformed into yeast strains that express either wild-type histone $\mathrm{H} 3$ or a mutant version of $\mathrm{H} 3$ (hht $2-K 4 R$, abbreviated $\mathrm{H} 3 \mathrm{~K} 4 \mathrm{R}$ ) that cannot be methylated by Set1 due to the replacement of lysine at position 4 with arginine (Fig. 4 and Supplementary Fig. 2). These yeast strains express H3 and $\mathrm{H} 4$ from a single gene cassette on a centromere-based plasmid. Expression of the un-methylatable K4R variant of histone H3 (H3K4R) caused reduced growth, which can be seen by comparing growth of strains expressing H3K4 to those expressing H3K4R (for example, compare extent of

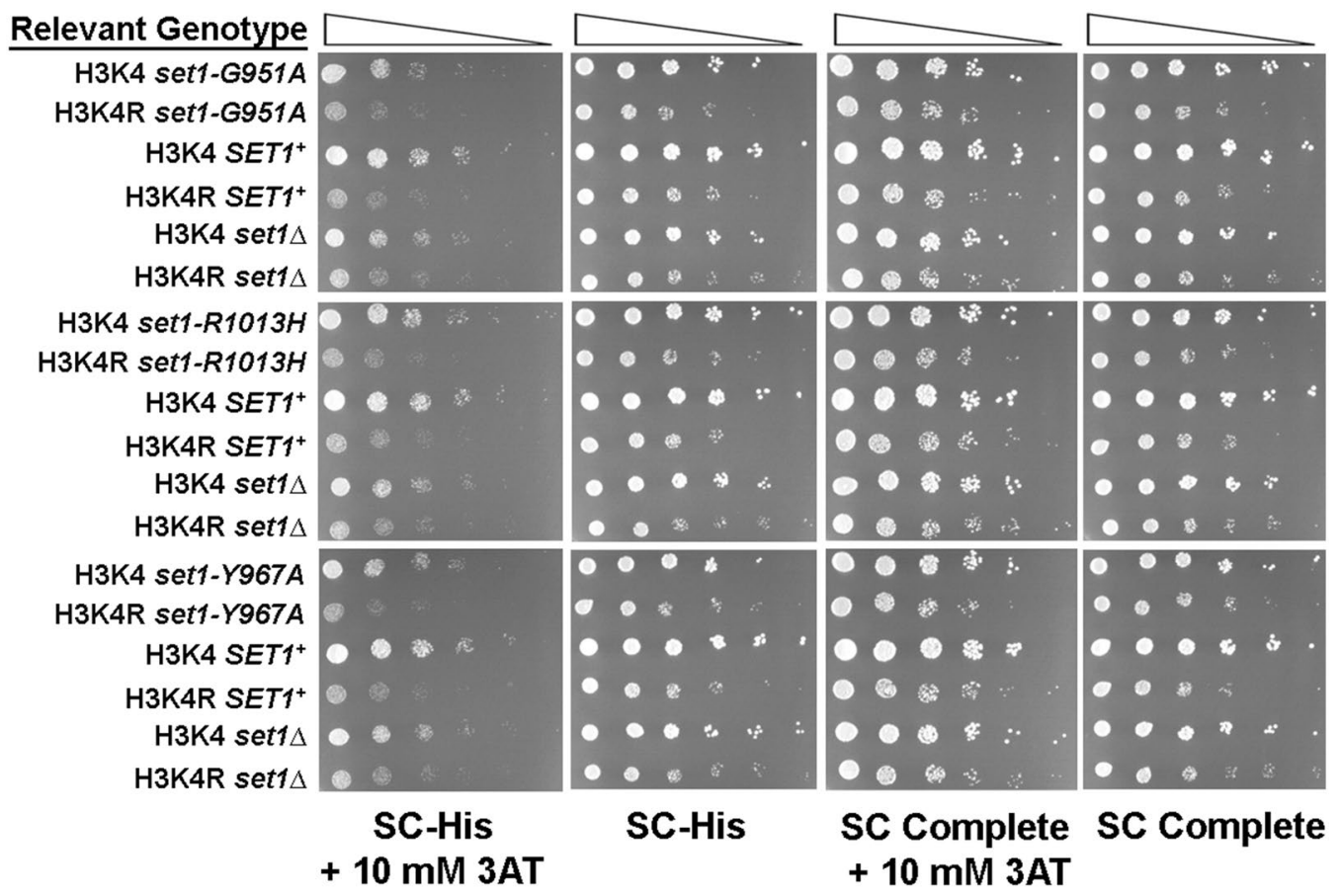

Fig. 4 Methylation of histone H3K4 by Set1 is required for robust growth on during histidine starvation. Five-fold serial dilutions of yeast cultures were spotted on to solid media, SC Complete and SCHis, with or without $10 \mathrm{mM}$ 3AT. The relevant genotypes listed on the left indicate yeast strains expressing wild-type or mutant alleles of SET1 and either wild-type histones $\mathrm{H} 3$ and $\mathrm{H} 4$ (H3K4) or mutant $\mathrm{H} 3$ K4R and wild-type $\mathrm{H} 4$, (H3K4R). Plates were incubated at $30{ }^{\circ} \mathrm{C}$ for $72 \mathrm{~h}$ prior to imaging $(n=3)$. Other labels, as in Fig. 2 
growth of H3K4 SETI ${ }^{+}$and H3K4R SETI ${ }^{+}$on each type of media, Fig. 4). It is clear that methylation of histone H3 by Set 1 is required for robust growth during amino acid starvation because the growth of yeast strain expressing unmethylatable H3K4R and $S_{E T 1^{+}}\left(\mathrm{H} 3 \mathrm{~K} 4 \mathrm{R} \mathrm{SET1^{+ }}\right)$ was the same as the H3K4R set1 $\Delta$ yeast strain on SC-His + 3AT agar (for example, top left panel, Fig. 4). The results indicate that histone H3 is the relevant target of Set1. Therefore, methylation of $\mathrm{H} 3 \mathrm{~K} 4$ by Set1 is required for robust growth of yeast cultures during histidine starvation and isoleucine and valine starvation (Supplementary Fig. 2).

As was observed with yeast strains carrying a normal complement of histone $\mathrm{H} 3$ and $\mathrm{H} 4$ genes (Fig. 2), the growth defect in the set $1 \Delta$ cultures is detected when compared to $\mathrm{H} 3 \mathrm{~K} 4 \mathrm{SETI}^{+}$or H3K4 set1-R1013H on SC-His + 3AT (Fig. 4). However, the extent of growth of the H3K4 set1G951A culture and the H3K4 set $1 \Delta$ cultures was similar on SC-His + 3AT (Fig. 4, top left panel), indicating the growth defect caused by histidine starvation was lost in set1-G951A mutant when coupled with reduced dosage of the histones $\mathrm{H} 3$ and $\mathrm{H} 4$ genes. One possibility is that in this genetic background with expression of histones $\mathrm{H} 3$ and $\mathrm{H} 4$ from a single $\mathrm{H} 3-\mathrm{H} 4$ cassette, the loss of H3K4me2 and H3K4me3 causes stronger growth defects under stress conditions. Altered phenotypes caused by expression of the histones $\mathrm{H} 3$ and H4 from a single H3-H4 cassette have been observed previously (Clark-Adams et al. 1988; Wyrick et al. 1999; Yu et al. 2019). The role of H3K4 methylation in expression of $H I S 3$ was explored further by measuring steady-state levels of HIS3 mRNA and the association of H3K4 methyl marks at the HIS3 gene in wild-type $S E T 1^{+}$strains and the hypomorphic set1 mutants.

\section{Histone H3K4 methylation by Set 1 is required for wild-type expression of the HIS3 gene in cultures grown in nutrient-stress conditions}

The level of HIS3 mRNA in cultures expressing wild-type $\mathrm{SETl}^{+}$or the set 1 amino-acid substitution variants was measured by Northern hybridization (Fig. 5). Histidine starvation was induced by adding $3 \mathrm{AT}$ to log-phase cultures for $1 \mathrm{~h}$ prior to isolation of RNA. HIS3 mRNA was increased 13.7-fold in $\mathrm{SETI}^{+}$cultures when histidine starvation was induced. In contrast, the increase in the HIS3 mRNA in the set $1 \Delta$ and set1-Y967A mutants was significantly lower than that in the $S E T 1^{+}$cultures. HIS3 mRNA levels were upregulated in the set1-G951A and set1-R1013H mutants and were not significantly different from those in the $S E T 1^{+}$cultures. From these results, we conclude that set1-G951A, an allele mainly capable of generating H3K4me1, supports the activation of transcription of the HIS3 gene under histidine-starvation conditions. Moreover, the growth defects observed in the set $1 \Delta$ and set $1-Y 967 \mathrm{~A}$ cultures under histidine-starvation

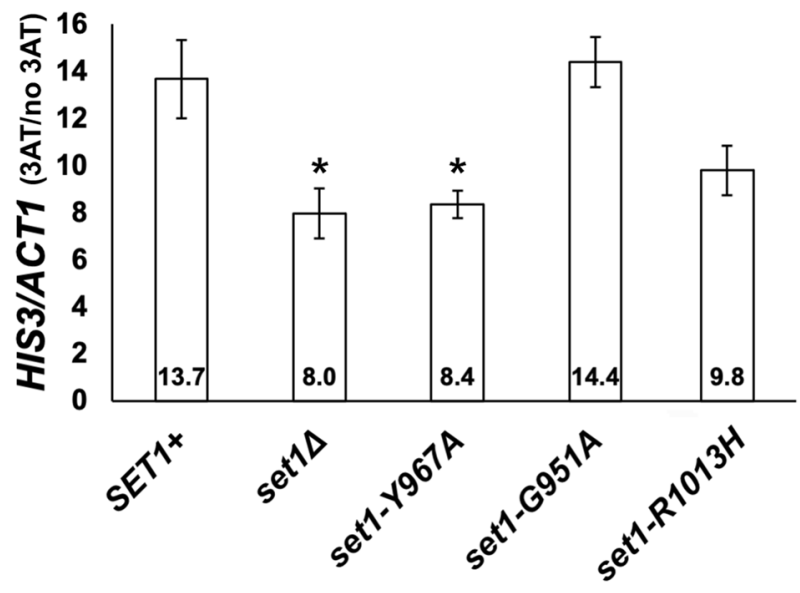

Fig. 5 HIS3 transcript levels are low in set1 null mutants under histidine-starvation conditions. Bar graph shows the steady-state HIS3 mRNA levels in total RNA isolated from wild-type strains and set1 mutants. The HIS3/ACT1 mRNA ratios for cultures grown in SCHis $+10 \mathrm{mM}$ 3AT were normalized to the ratios from the same cultures grown in SC-His (3AT/no 3AT). The values of the 3AT/no 3AT ratios were compared using the Mann Whitney $U$ test (Allaire 2012); SET1 ${ }^{+}, 13.7 \pm 1.7 ; \operatorname{set} 1 \Delta, 8.0 \pm 1.1 ;$ set1-Y967A, 8.4 \pm 0.6 ; set1-G951A, $14.4 \pm 1.1 ; \quad$ set1-Y967F, $13.5 \pm 1.2 ;$ set1-R1013H, $9.8 \pm 1.1$. The set $1 \Delta$ and set $1-Y 967 A$ mutants had significantly lower $H I S 3$ mRNA levels than the wild-type $S E T 1^{+}\left({ }^{*} p=0.02 S E T 1^{+}\right.$vs. set1 1 and $S E T 1^{+}$vs. set1-Y967A). The level of HIS3 mRNA in the set1-G951A mutant was similar to wild-type Set1 and significantly different from the $\mathrm{H} 3 \mathrm{~K} 4$ methylation null mutants $\left({ }^{*} p=0.02\right.$ set 1 $G 951 A$ vs. set $1 \Delta, * p=0.035$ set $1-G 951 A$ vs. set1-Y967A). Error bars represent standard error of the mean, SEM $\left(n=6\right.$ for $S E T 1^{+}$, set $1 \Delta$ and set $1-Y 967 F, n=5$ for set1-Y967A and set1-R013H, $n=3$ for set 1 G951A)

conditions (Fig. 2B) are likely to be due to defective induction of HIS3. Even though the average HIS3:ACTI level in the set 1-R1013H mutant under histidine-starvation conditions was higher than that from the set1 $\Delta$ and set1-Y967A cultures, the level was not statistically different from either the $S E T 1^{+}$or set1 $\Delta$ and set1-Y967A mutants. This situation was most likely caused by variation among the five samples used to analyze the HIS3:ACTl level in the set1-R1013H mutant.

\section{Histone H3K4 methylation patterns indicate that H3K4me1 supports induction of the HIS3 gene during histidine starvation}

To evaluate the presence of H3K4 methyl marks at the HIS3 gene during histidine starvation, ChIPs were performed to measure $\mathrm{H} 3 \mathrm{~K} 4 \mathrm{me} 1, \mathrm{H} 3 \mathrm{~K} 4 \mathrm{me} 2$ and $\mathrm{H} 3 \mathrm{~K} 4 \mathrm{me} 3$ at the HIS3 promoter and the $5^{\prime}$ and $3^{\prime}$ ends of the HIS3 ORF (Fig. 6A, B). The distribution of H3K4 methyl marks was also determined at the promoter of the ACTl gene and an intergenic region on chromosome VIII (Supplementary Fig. 3). ChIP samples from the set $1 \Delta$ mutant were evaluated 

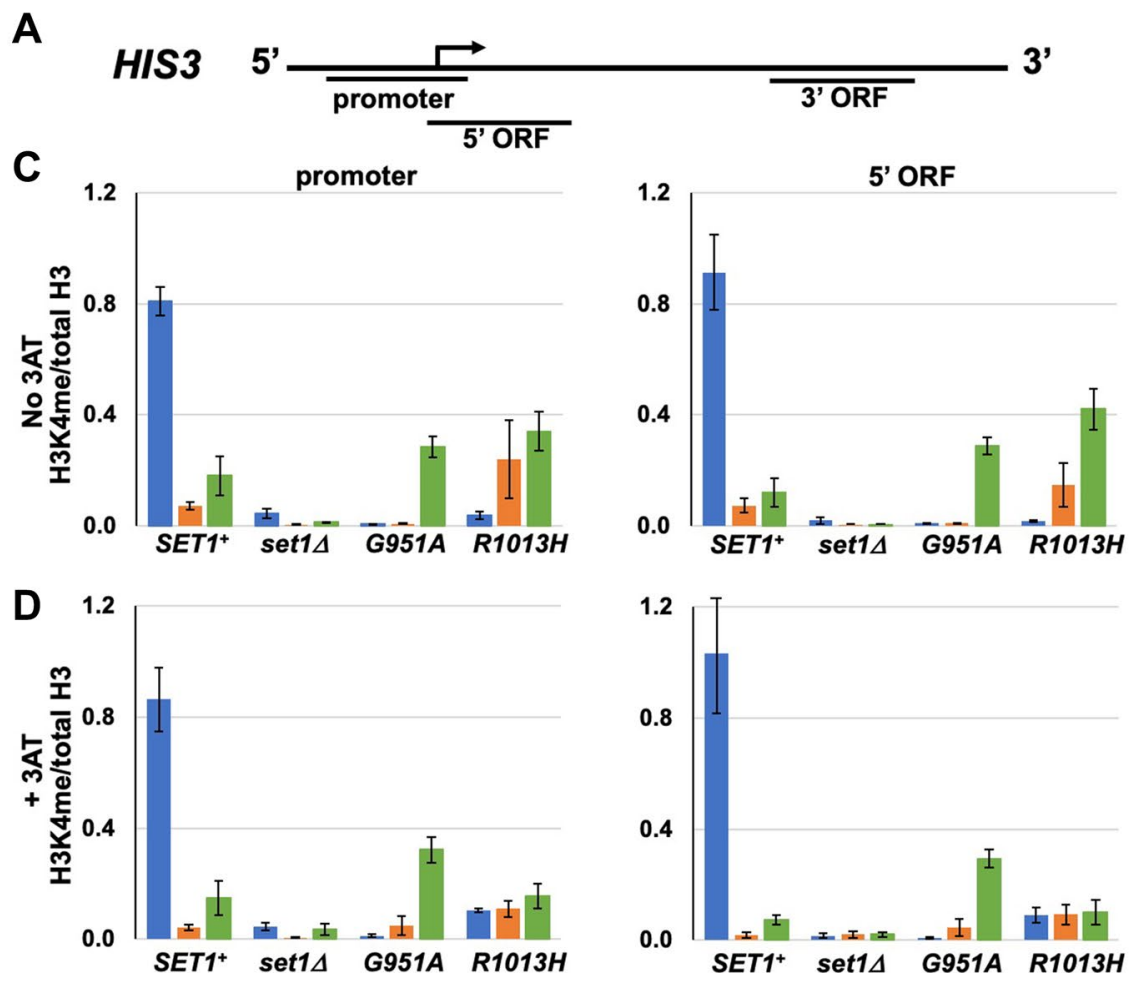

B
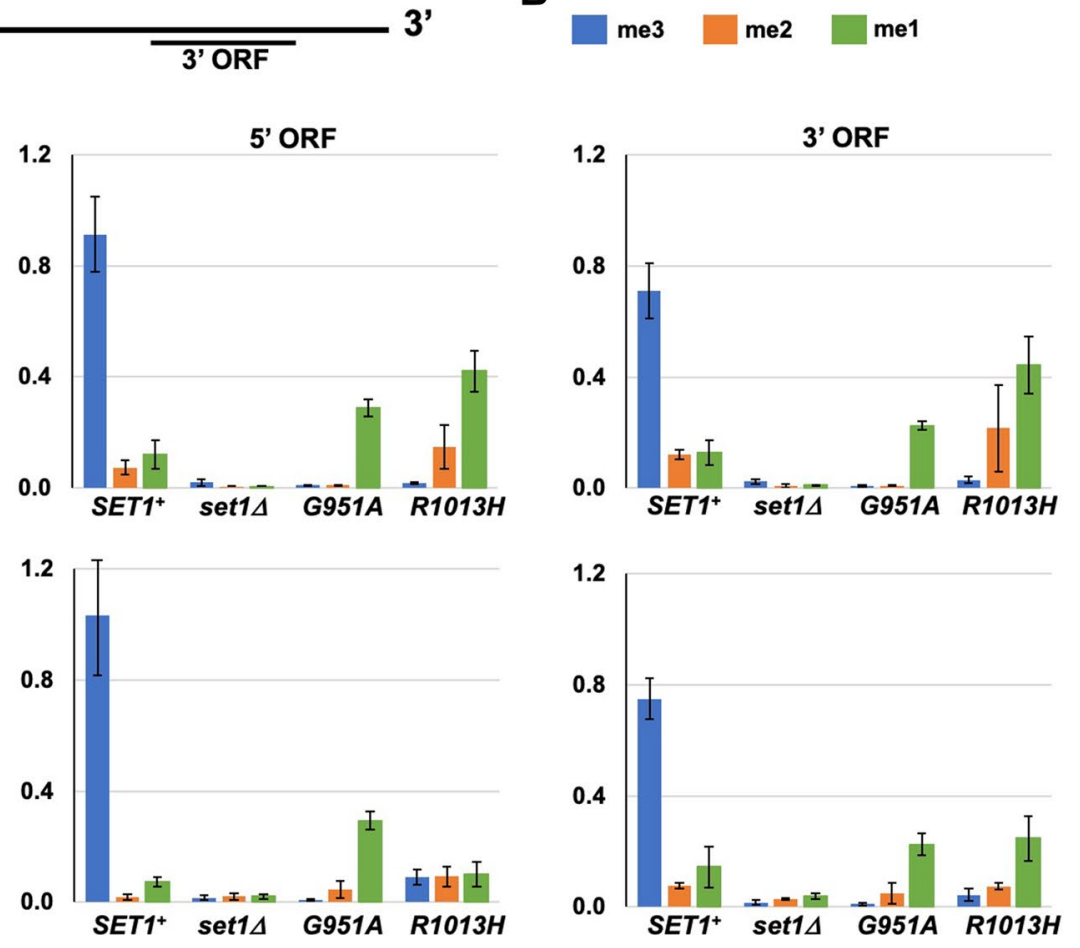

Fig. 6 Distribution of $\mathrm{H} 3 \mathrm{~K} 4 \mathrm{me}$ marks at three positions of the HIS3 gene. A Schematic showing the regions of HIS3 gene (promoter, 5' ORF and 3' ORF) evaluated by qPCR after ChIP for H3K4me1, H3K4me2 and H3K4me3. B Key to graph. C Association of H3K4me at the HIS3 promoter, 5' ORF and $3^{\prime}$ ORF in yeast cultures grown in SC-His. D Association of $\mathrm{H} 3 \mathrm{~K} 4 \mathrm{me}$ at the HIS3 promoter, 5' ORF and $3^{\prime}$ ORF in yeast cultures grown in SC-HIS + $10 \mathrm{mM}$ 3AT. See Supplementary Table 3 for statistical analysis; error bars, $( \pm$ SEM, $n=4)$

presence of 3AT (Fig. 6C, D, Supplementary Fig. 3). Likewise, $\mathrm{H} 3 \mathrm{~K} 4 \mathrm{me} 1$ and $\mathrm{H} 3 \mathrm{~K} 4 \mathrm{me} 2$ were detected above background at the HIS3 promoter and the $5^{\prime}$ and $3^{\prime}$ ORF regions in the set1-R1013H mutant in absence of 3AT (Fig. 6C). For the most part, the association of H3K4me3 at the three regions of $H I S 3$ gene, the $A C T 1$ promoter and the intergenic region in the set1-G951A and set1-R1013H mutants grown with or without $3 \mathrm{AT}$ were similar to background (Fig. 6C, D, Supplementary Fig. 3). An exception was seen at the HIS3 promoter in the set $1-\mathrm{R} 1013 \mathrm{H}$ cultures grown in the presence of $3 \mathrm{AT}$ where the H3K4me3 level was above background (Fig. 6D). The level of $\mathrm{H} 3 \mathrm{~K} 4 \mathrm{me} 2$ at the HIS3 promoter was also above background in set $1-R 1013 H$ cultures grown in $3 \mathrm{AT}$ (Fig. 6D). The increase in $\mathrm{H} 3 \mathrm{~K} 4 \mathrm{me} 2$ and $\mathrm{H} 3 \mathrm{~K} 4 \mathrm{me} 3$ at the HIS3 promoter in the set $1-\mathrm{R} 1013 \mathrm{H}$ mutant grown in 3AT may reflect an increase in transcription by Pol II when cells are starved for histidine. The result also indicates that the HMTase encoded by the set $1-R 1013 H$ allele is able to produce $\mathrm{H} 3 \mathrm{~K} 4 \mathrm{me} 3$ at low levels.

It was surprising that the levels of $\mathrm{H} 3 \mathrm{~K} 4 \mathrm{me} 1, \mathrm{H} 3 \mathrm{~K} 4 \mathrm{me} 2$ and $\mathrm{H} 3 \mathrm{~K} 4 \mathrm{me} 3$ associated with the HIS3 promoter, $5^{\prime} \mathrm{ORF}$ and $3^{\prime}$ ORF in wild-type $\mathrm{SETI}^{+}$cultures were not significantly increased in cultures grown in presence of $3 \mathrm{AT}$, $A C T 1$ promoter in the set1-G951A mutant in the absence and 
conditions that we know cause an increase in steady-state HIS3 mRNA (Fig. 5, Supplementary Table 3). Likewise, the levels of $\mathrm{H} 3 \mathrm{~K} 4 \mathrm{me} 1 / 2 / 3$ associated with the HIS3 promoter, 5' ORF and 3' ORF in the set1-G951A mutant were similar in cultures grown with and without $3 \mathrm{AT}$. These results demonstrate that major changes in the levels of H3K4me3, $\mathrm{H} 3 \mathrm{~K} 4 \mathrm{me} 2$ and $\mathrm{H} 3 \mathrm{~K} 4 \mathrm{me} 1$ at the HIS3 promoter, 5' ORF and $3^{\prime}$ ORF are not necessary for induction of the HIS3 gene during histidine starvation caused by treatment with 3AT. Two statistically significant differences in $\mathrm{H} 3 \mathrm{~K} 4$ methylation were detected in the set1-R1013H mutant when comparing ChIP data from cultures growth with $3 \mathrm{AT}$ to those grown without 3AT: the level of H3K4me3 was higher at the HIS3 promoter and the level of $\mathrm{H} 3 \mathrm{~K} 4 \mathrm{me} 1$ was lower at the HIS3 5' ORF (Fig. 6). Gene expression and ChIP experiments focusing on genes other than HIS3 should provide clarity regarding the function of set $1-R 1013 \mathrm{H}$ mutant.

The growth phenotypes observed in a set $1 \Delta$ mutant indicate that $\mathrm{H} 3 \mathrm{~K} 4$ methylation is required for robust growth and induction of HIS 3 transcription during histidine starvation. The results show that wild-type growth and induction of the HIS3 gene occurs in the set1-G951A mutant despite a lack of $\mathrm{H} 3 \mathrm{~K} 4 \mathrm{me} 3$ at the HIS3 promoter and 5' ORF. From the data, we conclude that $\mathrm{H} 3 \mathrm{~K} 4 \mathrm{me} 1$ supports transcription of the HIS3 gene under histidine-starvation conditions and the response does not rely on $\mathrm{H} 3 \mathrm{~K} 4 \mathrm{me} 2$ and $\mathrm{H} 3 \mathrm{~K} 4 \mathrm{me} 3$. The implications of these findings with respect to transcription are discussed below.

\section{Discussion}

Studies in S. cerevisiae have shown that H3K4me1 inhibits RSC-independent chromatin remodeling thereby preventing the induction of osmostress genes (Nadal-Ribelles et al. 2015). In higher eukaryotes, H3K4me 1 is associated with transcriptional silencing (Cheng et al. 2014). In contrast to these repressive roles, the work here using partial-function variants of the HMTase Set1 shows that H3K4me1 supports activation of Pol II transcription when S. cerevisiae is subjected to nutrient starvation. Growth defects observed in a set $1 \Delta$ mutant under amino-acid starvation are rescued by an H3K4me1-proficient allele, set1-G951A. In the set1-G951A mutant, $\mathrm{H} 3 \mathrm{~K} 4 \mathrm{me} 1$ is the predominant $\mathrm{H} 3 \mathrm{~K} 4$ methyl mark at the $H I S 3$ promoter during gene induction and $\mathrm{H} 3 \mathrm{~K} 4 \mathrm{me} 3$ is not detected (Figs. 1, 5, 6). Therefore, activation of the HIS3 gene in the set1-G951A mutant cannot be attributed to the accumulation of $\mathrm{H} 3 \mathrm{~K} 4 \mathrm{me} 3$ at the HIS 3 promoter. These findings indicate that $\mathrm{H} 3 \mathrm{~K} 4 \mathrm{me} 1$ supports induction of the HIS3 gene in the absence of higher-order $\mathrm{H} 3 \mathrm{~K} 4$ methylation. It is possible that other genes required for histidine biosynthesis are also regulated by H3K4me1. These genes will be investigated in future.
Growth defects were detected in set $1 \Delta$ mutants grown under isoleucine-valine starvation conditions, and these were rescued by the $S E T 1^{+}$, set1-G951A, set1-R1013H alleles, but not by set1-Y967A, which is defective for H3K4 methylation (Fig. 3). The data suggest that induction of at least one of the genes required for the biosynthesis of isoleucine and valine occurs in cells with $\mathrm{H} 3 \mathrm{~K} 4 \mathrm{me} 1$ that lack H3K4me3. In future, S. cerevisiae genes that are regulated by $\mathrm{H} 3 \mathrm{~K} 4 \mathrm{me} 1$ will be identified on a genome-wide scale using the set1-G951A mutant in RNA-seq and ChIP-seq experiments.

The three states of H3K4 methylation play different roles in gene expression (Kusch 2012; Pokholok et al. 2005). Much of the existing literature on H3K4 methylation focuses on the role of H3K4me3 in active transcription (Kusch 2012; Musselman et al. 2012; Pray-Grant et al. 2005; Schneider et al. 2005; Taverna et al. 2006), although there are several examples of genes that require $\mathrm{H} 3 \mathrm{~K} 4 \mathrm{me} 3$ for repression (for example see, Carvin and Kladde 2004; Weiner et al. 2012)). As expected from previous work (Liu et al. 2005; Pokholok et al. 2005; Soares et al. 2017), ChIP analysis of the HIS3 gene showed that the three forms of K4-methylated $\mathrm{H} 3$ are associated with the HIS3 promoter and the $5^{\prime}$ and $3^{\prime}$ regions of the HIS3 ORF in $\mathrm{SETI}^{+}$cultures. The highest H3K4me3 signals were at the promoter and $5^{\prime}$ end of the HIS3 ORF. $\mathrm{H} 3 \mathrm{~K} 4 \mathrm{me} 2$ levels were lower than those of H3K4me3 and $\mathrm{H} 3 \mathrm{~K} 4 \mathrm{me} 1$, and H3K4me1 levels were lower than those of H3K4me3 (Fig. 6). The H3K4 methylation profile of the $\mathrm{HIS3}$ gene in $\mathrm{SETl}^{+}$cultures (Fig. 6) is similar to the profiles reported in previous publications (Ramakrishnan et al. 2016; Soares et al. 2017).

Histidine starvation triggered by 3AT causes an increase in HIS3 mRNA (Hill et al. 1986). The work here shows that after one hour of induction of histidine starvation, there was a greater than 13-fold increase in HIS3 mRNA in SETI ${ }^{+}$ cultures (Fig. 5). It is surprising that this increase in HIS3 mRNA was not accompanied by an increase in the levels of H3K4 methyl marks at the HIS3 promoter in $\mathrm{SETI}^{+}$cultures (Fig. 6C, D). Based on these findings, we conclude that $\mathrm{H} 3 \mathrm{~K} 4$ methylation alone is unlikely to determine the transcriptional response to histidine starvation at the HIS3 gene. Changes in the levels of other histone modifications, such as acetylation, in combination with $\mathrm{H} 3 \mathrm{~K} 4$ methylation, are likely to be required to recruit transcription effectors responsible for induction of the HIS3 gene under histidinestarvation conditions. This possibility is reminiscent of the role of $\mathrm{H} 3 \mathrm{~K} 4 \mathrm{me} 1$ at enhancers and promoters in eukaryotic cells.

$\mathrm{H} 3 \mathrm{~K} 4 \mathrm{me} 1$ is found at enhancers and precedes acetylation of H3K27 (Calo and Wysocka 2013). These chromatin marks support enhancer-promoter interactions and transcription of enhancer RNAs (Creyghton et al. 2010; Kang et al. 2021). $\mathrm{H} 3 \mathrm{~K} 4 \mathrm{me} 1$ promotes interactions between the enhancers 
and gene promoters by facilitating the binding of chromatin remodelers (Local et al. 2018; Yan et al. 2018). Surprisingly, catalytically defective COMPASS-like HMTases in mammals have also been shown to facilitate enhancer-promoter interactions, suggesting that is an $\mathrm{H} 3 \mathrm{~K} 4 \mathrm{me} 1$-independent mechanism that supports enhancer-mediated effects on gene expression (Dorighi et al. 2017; Rickels et al. 2017). Unlike catalytically defective Set1-like HMTases at enhancers, the methylation-defective set1-Y967A allele did not support induction of $H I S 3$ (Fig. 5) and behaved like the set $1 \Delta$ mutant (Figs. 1, 2, 3, 4, 5). Previous work suggested that the set1Y967A mutant is unable to methylate Dam1, a non-histone target of the Set1, despite the presence of wild-type levels of Set1-Y967A protein in whole cell extracts (Williamson et al. 2013). The results obtained with the set1-Y967A mutant support the conclusion that Set1 HMTase activity is required for upregulation of HIS3 gene expression during histidine starvation

The association of $\mathrm{H} 3 \mathrm{~K} 4 \mathrm{me} 1$ with enhancers in higher eukaryotes is well established. Recent work revealed that $\mathrm{H} 3 \mathrm{~K} 4 \mathrm{me} 1$ at promoters in human and murine germ cells can provide information about the transcription potential of a gene (Bae and Lesch 2020). The authors concluded that H3K4me1 found together with H3K4me3 and H3K27me3 denotes a transcriptionally poised promoter and they speculated that the presence of $\mathrm{H} 3 \mathrm{~K} 4 \mathrm{me} 1$ at a poised promoter may reduce the action of DNA methyltransferases, essentially providing a mechanism to maintain the promoter in a neutral state that can be activated. Other studies have shown that $\mathrm{H} 3 \mathrm{~K} 4 \mathrm{me} 1$ is correlated with regions of intermediate DNA methylation (Sharifi-Zarchi et al. 2017). A clear picture of the functions of $\mathrm{H} 3 \mathrm{~K} 4 \mathrm{me} 1$ at promoters is still emerging.

The initiation of Pol II transcription requires the assembly of transcription factors at gene promoters. At HIS3 and other genes, Gcn4 recruits the SAGA complex (Spt-AdaGcn5 acetyltransferase) to gene promoters (Kuo et al. 2000). Gcn4 also interacts with SWI/SNF, the SRB/Mediator complex, RNA polymerase II, TFIID, and NuA4 (Ginsburg et al. 2009; Natarajan et al. 1999; Swanson et al. 2003). Identification of proteins in $S$. cerevisiae that read $\mathrm{H} 3 \mathrm{~K} 4 \mathrm{me} 1$ will help elucidate $\mathrm{H} 3 \mathrm{~K} 4 \mathrm{me} 1$-dependent mechanisms of transcription activation. Previous work in human cells showed that the chromodomain of the acetyltransferase, Tip60, recognizes H3K4me1 at certain enhancer elements (Jeong et al. 2011). In future, we will identify transcriptional effectors that read $\mathrm{H} 3 \mathrm{~K} 4 \mathrm{me} 1$ and determine if these contribute to the activation of transcription at HIS3 and other genes.

H3K4 methyltransferases are conserved across species from yeast to humans and have important roles in regulation of gene expression (reviewed in Shilatifard (2012)). The involvement of $\mathrm{H} 3 \mathrm{~K} 4 \mathrm{me} 3$ in gene activation (Pray-Grant et al. 2005) and repression (Shi et al. 2006) illustrates the complexity of the regulation mediated by Set1 and Set1like methyltransferase. The identification and characterization of H3K4me1-mediated mechanisms will contribute to our understanding of transcriptional regulation and gene expression.

Supplementary Information The online version contains supplementary material available at https://doi.org/10.1007/s00294-022-01226-2.

Acknowledgements The authors acknowledge Indranil Malik and Craig Kaplan for thoughtful discussions and suggesting the use of 3AT as a transcriptional inducer, Amber Wadle for helpful discussions and John Mueller for reading the manuscript.

Author contributions SHP, RJ, ND and MB conceived the experiments. MB generated yeast strains. ND and RJ generated data. ND and MB wrote the manuscript. After review and comments, the manuscript was approved by all authors.

Funding This work is supported by the USDA National Institute of Food and Agriculture, Hatch project \# 7000709 and Texas A\&M AgriLife Research.

Availability of data and material The authors will make all data and unique research materials and data freely available to other investigators.

Code availability Not applicable.

\section{Declarations}

Conflict of interest Not applicable.

Ethics approval Not applicable.

Consent to participate Not applicable.

Consent for publication Not applicable.

Open Access This article is licensed under a Creative Commons Attribution 4.0 International License, which permits use, sharing, adaptation, distribution and reproduction in any medium or format, as long as you give appropriate credit to the original author(s) and the source, provide a link to the Creative Commons licence, and indicate if changes were made. The images or other third party material in this article are included in the article's Creative Commons licence, unless indicated otherwise in a credit line to the material. If material is not included in the article's Creative Commons licence and your intended use is not permitted by statutory regulation or exceeds the permitted use, you will need to obtain permission directly from the copyright holder. To view a copy of this licence, visit http://creativecommons.org/licenses/by/4.0/.

\section{References}

Allaire J (2012) RStudio: integrated development environment for R. Boston 537:538

Bae S, Lesch BJ (2020) H3K4me1 distribution predicts transcription state and poising at promoters. Front Cell Dev Biol 8:289 
Bae HJ, Dubarry M, Jeon J, Soares LM, Dargemont C, Kim J, Geli V, Buratowski S (2020) The Set1 N-terminal domain and Swd2 interact with RNA polymerase II CTD to recruit COMPASS. Nat Commun 11:2181. https://doi.org/10.1038/s41467-020-16082-2

Bernstein BE, Kamal M, Lindblad-Toh K, Bekiranov S, Bailey DK, Huebert DJ, McMahon S, Karlsson EK, Kulbokas EJ, Gingeras TR, Schreiber SL, Lander ES (2005) Genomic maps and comparative analysis of histone modifications in human and mouse. Cell 120:169-181. https://doi.org/10.1016/j.cell.2005.01.001

Breen TR (1999) Mutant alleles of the Drosophila trithorax gene produce common and unusual homeotic and other developmental phenotypes. Genetics 152:319-344

Brennan MB, Struhl K (1980) Mechanisms of increasing expression of a yeast gene in Escherichia coli. J Mol Biol 136:333-338. https:// doi.org/10.1016/0022-2836(80)90377-0

Briggs SD, Bryk M, Strahl BD, Cheung WL, Davie JK, Dent SY, Winston F, Allis CD (2001) Histone H3 lysine 4 methylation is mediated by Set 1 and required for cell growth and rDNA silencing in Saccharomyces cerevisiae. Genes Dev 15:3286-3295. https://doi. org/10.1101/gad.940201

Bryk M, Briggs SD, Strahl BD, Curcio MJ, Allis CD, Winston F (2002) Evidence that Set1, a factor required for methylation of histone $\mathrm{H} 3$, regulates rDNA silencing in $S$. cerevisiae by a Sir2-independent mechanism. Curr Biol 12:165-170. https://doi.org/10.1016/ S0960-9822(01)00652-2

Calo E, Wysocka J (2013) Modification of enhancer chromatin: what, how, and why? Mol Cell 49:825-837. https://doi.org/10.1016/j. molcel.2013.01.038

Carvin CD, Kladde MP (2004) Effectors of lysine 4 methylation of histone $\mathrm{H} 3$ in Saccharomyces cerevisiae are negative regulators of PHO5 and GAL1-10. J Biol Chem 279:33057-33062. https:// doi.org/10.1074/jbc.M405033200

Castillo J, López-Rodas G, Franco L (2017) Histone post-translational modifications and nucleosome organisation in transcriptional regulation: some open questions. In: Atassi MZ (ed) Protein reviews, vol 18. Springer Singapore, Singapore, pp 65-92

Catarino RR, Stark A (2018) Assessing sufficiency and necessity of enhancer activities for gene expression and the mechanisms of transcription activation. Genes Dev 32:202-223. https://doi.org/ 10.1101/gad.310367.117

Cenik BK, Shilatifard A (2021) COMPASS and SWI/SNF complexes in development and disease. Nat Rev Genet 22:38-58. https://doi. org/10.1038/s41576-020-0278-0

Chatterjee N, Sinha D, Lemma-Dechassa M, Tan S, Shogren-Knaak MA, Bartholomew B (2011) Histone H3 tail acetylation modulates ATP-dependent remodeling through multiple mechanisms. Nucleic Acids Res 39:8378-8391. https://doi.org/10.1093/nar/ gkr535

Cheng J, Blum R, Bowman C, Hu D, Shilatifard A, Shen S, Dynlacht BD (2014) A role for H3K4 monomethylation in gene repression and partitioning of chromatin readers. Mol Cell 53:979-992. https://doi.org/10.1016/j.molcel.2014.02.032

Clark-Adams CD, Norris D, Osley MA, Fassler JS, Winston F (1988) Changes in histone gene dosage alter transcription in yeast. Genes Dev 2:150-159

Côté J, Peterson CL, Workman JL (1998) Perturbation of nucleosome core structure by the SWI/SNF complex persists after its detachment, enhancing subsequent transcription factor binding. Proc Natl Acad Sci USA 95:4947-4952. https://doi.org/10.1073/pnas. 95.9.4947

Creyghton MP, Cheng AW, Welstead GG, Kooistra T, Carey BW, Steine EJ, Hanna J, Lodato MA, Frampton GM, Sharp PA, Boyer LA, Young RA, Jaenisch R (2010) Histone H3K27ac separates active from poised enhancers and predicts developmental state. Proc Natl Acad Sci USA 107:21931-21936. https://doi.org/10. 1073/pnas.1016071107
Dillon SC, Zhang X, Trievel RC, Cheng X (2005) The SET-domain protein superfamily: protein lysine methyltransferases. Genome Biol 6:227. https://doi.org/10.1186/gb-2005-6-8-227

Dorighi KM, Swigut T, Henriques T, Bhanu NV, Scruggs BS, Nady N, Still CD 2nd, Garcia BA, Adelman K, Wysocka J (2017) Mll3 and Mll4 facilitate enhancer RNA synthesis and transcription from promoters independently of H3K4 monomethylation. Mol Cell 66:568-576.e564. https://doi.org/10.1016/j.molcel.2017.04.018

Falco SC, Dumas KS (1985) Genetic analysis of mutants of Saccharomyces cerevisiae resistant to the herbicide sulfometuron methyl. Genetics 109:21-35. https://doi.org/10.1093/genetics/109.1.21

Falco SC, Dumas KS, Livak KJ (1985) Nucleotide sequence of the yeast $I L V 2$ gene which encodes acetolactate synthase. Nucleic Acids Res 13:4011-4027. https://doi.org/10.1093/nar/13.11.4011

Fink GR (1964) Gene-enzyme relations in histidine biosynthesis in yeast. Science 146:525. https://doi.org/10.1126/science.146.3643. 525

Froimchuk E, Jang Y, Ge K (2017) Histone H3 lysine 4 methyltransferase KMT2D. Gene 627:337-342. https://doi.org/10.1016/j. gene.2017.06.056

Ginsburg DS, Govind CK, Hinnebusch AG (2009) NuA4 lysine acetyltransferase Esa1 is targeted to coding regions and stimulates transcription elongation with Gen5. Mol Cell Biol 29:6473-6487. https://doi.org/10.1128/MCB.01033-09

Han M, Grunstein M (1988) Nucleosome loss activates yeast downstream promoters in vivo. Cell 55:1137-1145. https://doi.org/10. 1016/0092-8674(88)90258-9

Hill DE, Hope IA, Macke JP, Struhl K (1986) Saturation mutagenesis of the yeast his 3 regulatory site: requirements for transcriptional induction and for binding by GCN4 activator protein. Science 234:451

Hinnebusch AG (2005) Translational regulation of GCN4 and the general amino acid control of yeast. Annu Rev Microbiol 59:407-450. https://doi.org/10.1146/annurev.micro.59.031805.133833

Hope IA, Struhl K (1985) GCN4 protein, synthesize in vitro, binds HIS3 regulatory sequences: implications for general control of amino acid biosynthetic genes in yeast. Cell 43:177-188. https:// doi.org/10.1016/0092-8674(85)90022-4

Hyun K, Jeon J, Park K, Kim J (2017) Writing, erasing and reading histone lysine methylations. Exp Mol Med 49:e324-e324. https:// doi.org/10.1038/emm.2017.11

Izban MG, Luse DS (1992) Factor-stimulated RNA polymerase II transcribes at physiological elongation rates on naked DNA but very poorly on chromatin templates. J Biol Chem 267:13647-13655

Jeong KW, Kim K, Situ AJ, Ulmer TS, An W, Stallcup MR (2011) Recognition of enhancer element-specific histone methylation by TIP60 in transcriptional activation. Nat Struct Mol Biol 18:13581365. https://doi.org/10.1038/nsmb.2153

Jiang D, Kong NC, Gu X, Li Z, He Y (2011) Arabidopsis COMPASSlike complexes mediate histone $\mathrm{H} 3$ lysine-4 trimethylation to control floral transition and plant development. PLoS Genet 7:e1001330. https://doi.org/10.1371/journal.pgen.1001330

Kandoth C, McLellan MD, Vandin F, Ye K, Niu B, Lu C, Xie M, Zhang Q, McMichael JF, Wyczalkowski MA, Leiserson MDM, Miller CA, Welch JS, Walter MJ, Wendl MC, Ley TJ, Wilson RK, Raphael BJ, Ding L (2013) Mutational landscape and significance across 12 major cancer types. Nature 502:333. https://doi.org/10. 1038/nature12634. https://www.nature.com/articles/nature12634\# supplementary-information

Kang Y, Kim YW, Kang J, Kim A (2021) Histone H3K4me1 and $\mathrm{H} 3 \mathrm{~K} 27$ ac play roles in nucleosome eviction and eRNA transcription, respectively, at enhancers. FASEB J 35:e21781. https://doi. org/10.1096/fj.202100488R

Kim T, Buratowski S (2009) Dimethylation of H3K4 by Set1 recruits the Set3 histone deacetylase complex to $5^{\prime}$ transcribed regions. Cell 137:259-272. https://doi.org/10.1016/j.cell.2009.02.045 
Kornberg RD, Thonmas JO (1974) Chromatin structure: oligomers of the histones. Science 184:865. https://doi.org/10.1126/scien ce. 184.4139.865

Krogan NJ, Dover J, Khorrami S, Greenblatt JF, Schneider J, Johnston M, Shilatifard A (2002) COMPASS, a histone H3 (lysine 4) methyltransferase required for telomeric silencing of gene expression. J Biol Chem 277:10753-10755

Kuo M-H, Allis CD (1998) Roles of histone acetyltransferases and deacetylases in gene regulation. BioEssays 20:615-626. https:// doi.org/10.1002/(SICI)1521-1878(199808)20:8\%3c615::AIDBIES4\%3e3.0.CO;2-H

Kuo M-H, vom Baur E, Struhl K, Allis CD (2000) Gen4 activator targets Gcn5 histone acetyltransferase to specific promoters independently of transcription. Mol Cell 6:1309-1320. https://doi.org/ 10.1016/S1097-2765(00)00129-5

Kusch T (2012) Histone H3 lysine 4 methylation revisited. Transcription 3:310-314. https://doi.org/10.4161/trns.21911

Latham JA, Chosed RJ, Wang S, Dent SY (2011) Chromatin signaling to kinetochores: transregulation of Dam1 methylation by histone H2B ubiquitination. Cell 146:709-719. https://doi.org/10.1016/j. cell.2011.07.025

Lee DY, Hayes JJ, Pruss D, Wolffe AP (1993) A positive role for histone acetylation in transcription factor access to nucleosomal DNA. Cell 72:73-84. https://doi.org/10.1016/0092-8674(93) 90051-Q

Lee J-S, Shukla A, Schneider J, Swanson SK, Washburn MP, Florens L, Bhaumik SR, Shilatifard A (2007) Histone crosstalk between H2B monoubiquitination and $\mathrm{H} 3$ methylation mediated by COMPASS. Cell 131:1084-1096. https://doi.org/10.1016/j.cell.2007.09.046

Lee KY, Chen Z, Jiang R, Meneghini MD (2018) H3K4 methylation dependent and independent chromatin regulation by JHD2 and SET1 in budding yeast. G3 (bethesda, Md) 8:1829-1839. https:// doi.org/10.1534/g3.118.200151

Li C, Mueller JE, Bryk M (2006) Sir2 represses endogenous polymerase II transcription units in the ribosomal DNA nontranscribed spacer. Mol Biol Cell 17:3848-3859. https://doi.org/10.1091/mbc. e06-03-0205

Liu CL, Kaplan T, Kim M, Buratowski S, Schreiber SL, Friedman N, Rando OJ (2005) Single-nucleosome mapping of histone modifications in S. cerevisiae. PLoS Biol 3:e328. https://doi.org/10. 1371/journal.pbio.0030328

Local A, Huang H, Albuquerque CP, Singh N, Lee AY, Wang W, Wang C, Hsia JE, Shiau AK, Ge K, Corbett KD, Wang D, Zhou H, Ren B (2018) Identification of $\mathrm{H} 3 \mathrm{~K} 4 \mathrm{me} 1$-associated proteins at mammalian enhancers. Nat Genet 50:73-82. https://doi.org/10.1038/ s41588-017-0015-6

Miller T, Krogan NJ, Dover J, Erdjument-Bromage H, Tempst P, Johnston M, Greenblatt JF, Shilatifard A (2001) COMPASS: a complex of proteins associated with a trithorax-related SET domain protein. Proc Natl Acad Sci USA 98:12902-12907. https://doi. org/10.1073/pnas.231473398

Morillon A, Karabetsou N, Nair A, Mellor J (2005) Dynamic lysine methylation on histone $\mathrm{H} 3$ defines the regulatory phase of gene transcription. Mol Cell 18:723-734. https://doi.org/10.1016/j. molcel.2005.05.009

Mueller JE, Canze M, Bryk M (2006) The requirements for COMPASS and Paf1 in transcriptional silencing and methylation of histone H3 in Saccharomyces cerevisiae. Genetics 173:557-567. https:// doi.org/10.1534/genetics.106.055400

Musselman CA, Lalonde M-E, Côté J, Kutateladze TG (2012) Perceiving the epigenetic landscape through histone readers. Nat Struct Mol Biol 19:1218-1227. https://doi.org/10.1038/nsmb.2436

Nadal-Ribelles M, Mas G, Millán-Zambrano G, Solé C, Ammerer G, Chávez S, Posas F, de Nadal E (2015) H3K4 monomethylation dictates nucleosome dynamics and chromatin remodeling at stress-responsive genes. Nucleic Acids Res 43:4937-4949. https:// doi.org/10.1093/nar/gkv220

Nagy PL, Griesenbeck J, Kornberg RD, Cleary ML (2002) A trithorax-group complex purified from Saccharomyces cerevisiae is required for methylation of histone H3. Proc Natl Acad Sci USA 99:90-94. https://doi.org/10.1073/pnas.221596698

Natarajan K, Jackson BM, Zhou H, Winston F, Hinnebusch AG (1999) Transcriptional activation by Gcn $4 p$ involves independent interactions with the SWI/SNF complex and the SRB/mediator. Mol Cell 4:657-664. https://doi.org/10.1016/S1097-2765(00)80217-8

$\mathrm{Ng} \mathrm{HH}$, Robert F, Young RA, Struhl K (2003) Targeted recruitment of Set1 histone methylase by elongating Pol II provides a localized mark and memory of recent transcriptional activity. Mol Cell 11:709-719. https://doi.org/10.1016/S1097-2765(03)00092-3

Nislow C, Ray E, Pillus L (1997) SET1, a yeast member of the trithorax family, functions in transcriptional silencing and diverse cellular processes. Mol Biol Cell 8:2421-2436. https://doi.org/10.1091/ mbc.8.12.2421

Pinskaya M, Morillon A (2009) Histone H3 lysine 4 di-methylation: a novel mark for transcriptional fidelity? Epigenetics 4:302-306

Pokholok DK, Harbison CT, Levine S, Cole M, Hannett NM, Lee TI, Bell GW, Walker K, Rolfe PA, Herbolsheimer E, Zeitlinger J, Lewitter F, Gifford DK, Young RA (2005) Genome-wide map of nucleosome acetylation and methylation in yeast. Cell 122:517 527. https://doi.org/10.1016/j.cell.2005.06.026

Pray-Grant MG, Daniel JA, Schieltz D, Yates JR, Grant PA (2005) Chd1 chromodomain links histone H3 methylation with SAGAand SLIK-dependent acetylation. Nature 433:434-438. https://doi. org/10.1038/nature03242

Qu Q, Takahashi Y-h, Yang Y, Hu H, Zhang Y, Brunzelle JS, Couture J-F, Shilatifard A, Skiniotis G (2018) Structure and conformational dynamics of a COMPASS histone H3K4 methyltransferase complex. Cell 174:1117-1126.e1112. https://doi.org/10.1016/j. cell.2018.07.020

Ramakrishnan S, Pokhrel S, Palani S, Pflueger C, Parnell TJ, Cairns BR, Bhaskara S, Chandrasekharan MB (2016) Counteracting H3K4 methylation modulators Set1 and Jhd2 co-regulate chromatin dynamics and gene transcription. Nat Commun 7:11949. https://doi.org/10.1038/ncomms11949

Rickels R, Herz H-M, Sze CC, Cao K, Morgan MA, Collings CK, Gause M, Takahashi Y-H, Wang L, Rendleman EJ, Marshall SA, Krueger A, Bartom ET, Piunti A, Smith ER, Abshiru NA, Kelleher NL, Dorsett D, Shilatifard A (2017) Histone H3K4 monomethylation catalyzed by Trr and mammalian COMPASS-like proteins at enhancers is dispensable for development and viability. Nat Genet 49:1647-1653. https://doi.org/10.1038/ng.3965

Roguev A, Schaft D, Shevchenko A, Pijnappel WW, Wilm M, Aasland R, Stewart AF (2001) The Saccharomyces cerevisiae Set1 complex includes an Ash2 homologue and methylates histone 3 lysine 4. EMBO J 20:7137-7148. https://doi.org/10.1093/emboj/ 20.24.7137

Rose MD, Winston F, Hieter P (1990) Methods in yeast genetics: a laboratory course manual. Cold Spring Harbor Laboratory Press, Cold Spring Harbor, NY

Ruault M, Brun ME, Ventura M, Roizès G, De Sario A (2002) MLL3, a new human member of the TRX/MLL gene family, maps to $7 \mathrm{q} 36$, a chromosome region frequently deleted in myeloid leukaemia. Gene 284:73-81. https://doi.org/10.1016/S0378-1119(02) 00392-X

Santos-Rosa H, Schneider R, Bernstein BE, Karabetsou N, Morillon A, Weise C, Schreiber SL, Mellor J, Kouzarides T (2003) Methylation of histone $\mathrm{H} 3 \mathrm{~K} 4$ mediates association of the Isw1p ATPase with chromatin. Mol Cell 12:1325-1332. https://doi.org/10.1016/ S1097-2765(03)00438-6

Schmitt ME, Brown TA, Trumpower BL (1990) A rapid and simple method for preparation of RNA from Saccharomyces cerevisiae. 
Nucleic Acids Res 18:3091-3092. https://doi.org/10.1093/nar/18. 10.3091

Schneider J, Wood A, Lee J-S, Schuster R, Dueker J, Maguire C, Swanson SK, Florens L, Washburn MP, Shilatifard A (2005) Molecular regulation of histone $\mathrm{H} 3$ trimethylation by COMPASS and the regulation of gene expression. Mol Cell 19:849-856. https://doi. org/10.1016/j.molcel.2005.07.024

Schrodinger, LLC (2015) The PyMOL molecular graphics system, version 1.8

Sharifi-Zarchi A, Gerovska D, Adachi K, Totonchi M, Pezeshk H, Taft RJ, Scholer HR, Chitsaz H, Sadeghi M, Baharvand H, ArauzoBravo MJ (2017) DNA methylation regulates discrimination of enhancers from promoters through a $\mathrm{H} 3 \mathrm{~K} 4 \mathrm{me} 1-\mathrm{H} 3 \mathrm{~K} 4 \mathrm{me} 3$ seesaw mechanism. BMC Genomics 18:964. https://doi.org/10.1186/ s12864-017-4353-7

Shi X, Hong T, Walter KL, Ewalt M, Michishita E, Hung T, Carney D, Peña P, Lan F, Kaadige MR, Lacoste N, Cayrou C, Davrazou F, Saha A, Cairns BR, Ayer DE, Kutateladze TG, Shi Y, Côté J, Chua KF, Gozani O (2006) ING2 PHD domain links histone H3 lysine 4 methylation to active gene repression. Nature 442:96-99. https://doi.org/10.1038/nature04835

Shilatifard A (2012) The COMPASS family of histone H3K4 methylases: mechanisms of regulation in development and disease pathogenesis. Annu Rev Biochem 81:65-95. https://doi.org/10.1146/ annurev-biochem-051710-134100

Sikorski RS, Hieter P (1989) A system of shuttle vectors and yeast host strains designed for efficient manipulation of DNA in Saccharomyces cerevisiae. Genetics 122:19-27

Slany RK (2009) The molecular biology of mixed lineage leukemia. Haematologica 94:984-993. https://doi.org/10.3324/haematol. 2008.002436

Soares LM, He PC, Chun Y, Suh H, Kim T, Buratowski S (2017) Determinants of histone H3K4 methylation patterns. Mol Cell 68(773-785):e776. https://doi.org/10.1016/j.molcel.2017.10.013

Sollier J, Lin W, Soustelle C, Suhre K, Nicolas A, Géli V, de La Roche S-A (2004) Set1 is required for meiotic S-phase onset, doublestrand break formation and middle gene expression. EMBO J 23:1957-1967. https://doi.org/10.1038/sj.emboj.7600204

Swanson MS, Malone EA, Winston F (1991) SPT5, an essential gene important for normal transcription in Saccharomyces cerevisiae, encodes an acidic nuclear protein with a carboxy-terminal repeat. Mol Cell Biol 11:3009-3019. https://doi.org/10.1128/mcb.11.6. 3009

Swanson MJ, Qiu H, Sumibcay L, Krueger A, Kim S-j, Natarajan K, Yoon S, Hinnebusch AG (2003) A multiplicity of coactivators is required by Gcn $4 p$ at individual promoters in vivo. Mol Cell Biol 23:2800-2820. https://doi.org/10.1128/mcb.23.8.2800-2820.2003

Takahashi Y-h, Westfield GH, Oleskie AN, Trievel RC, Shilatifard A, Skiniotis G (2011) Structural analysis of the core COMPASS family of histone H3K4 methylases from yeast to human. Proc Natl Acad Sci USA 108:20526-20531. https://doi.org/10.1073/ pnas. 1109360108

Taverna SD, Ilin S, Rogers RS, Tanny JC, Lavender H, Li H, Baker L, Boyle J, Blair LP, Chait Brian T, Patel DJ, Aitchison JD, Tackett
AJ, Allis CD (2006) Yng1 PHD finger binding to H3 trimethylated at K4 promotes NuA3 HAT activity at K14 of H3 and transcription at a subset of targeted ORFs. Mol Cell 24:785-796. https://doi.org/10.1016/j.molcel.2006.10.026

Vermeulen M, Mulder KW, Denissov S, Pijnappel WWMP, van Schaik FMA, Varier RA, Baltissen MPA, Stunnenberg HG, Mann M, Timmers HTM (2007) Selective anchoring of TFIID to nucleosomes by trimethylation of histone $\mathrm{H} 3$ lysine 4. Cell 131:58-69. https://doi.org/10.1016/j.cell.2007.08.016

Wang Y, Ding Z, Liu X, Bao Y, Huang M, Wong CCL, Hong X, Cong Y (2018) Architecture and subunit arrangement of the complete Saccharomyces cerevisiae COMPASS complex. Sci Rep 8:17405. https://doi.org/10.1038/s41598-018-35609-8

Wasylyk B, Chambon P (1979) Transcription by eukaryotic RNA polymerases A and B of chromatin assembled in vitro. Eur J Biochem 98:317-327. https://doi.org/10.1111/j.1432-1033.1979.tb13191.x

Weiner A, Chen HV, Liu CL, Rahat A, Klien A, Soares L, Gudipati M, Pfeffner J, Regev A, Buratowski S, Pleiss JA, Friedman N, Rando OJ (2012) Systematic dissection of roles for chromatin regulators in a yeast stress response. PLoS Biol 10:e1001369. https://doi.org/ 10.1371/journal.pbio.1001369

Williamson K, Schneider V, Jordan RA, Mueller JE, Pozzi MH, Bryk M (2013) Catalytic and functional roles of conserved amino acids in the SET domain of the $S$. cerevisiae lysine methyltransferase Set1. PLoS ONE 8:e57974

Workman JL, Kingston RE (1998) Alteration of nucleosome structure as a mechanism of transcriptional regulation. Annu Rev Biochem 67:545-579. https://doi.org/10.1146/annurev.biochem.67.1.545

Wyrick JJ, Holstege FC, Jennings EG, Causton HC, Shore D, Grunstein M, Lander ES, Young RA (1999) Chromosomal landscape of nucleosome-dependent gene expression and silencing in yeast. Nature 402:418-421. https://doi.org/10.1038/46567

Yan J, Chen S-AA, Local A, Liu T, Qiu Y, Dorighi KM, Preissl S, Rivera CM, Wang C, Ye Z, Ge K, Hu M, Wysocka J, Ren B (2018) Histone $\mathrm{H} 3$ lysine 4 monomethylation modulates long-range chromatin interactions at enhancers. Cell Res 28:204-220. https://doi. org/10.1038/cr.2018.1

Yu R, Sun L, Sun Y, Han X, Qin L, Dang W (2019) Cellular response to moderate chromatin architectural defects promotes longevity. Sci Adv 5:eaav1165. https://doi.org/10.1126/sciadv.aav1165

Zhang K, Lin W, Latham JA, Riefler GM, Schumacher JM, Chan C, Tatchell K, Hawke DH, Kobayashi R, Dent SY (2005) The Set1 methyltransferase opposes Ipl1 aurora kinase functions in chromosome segregation. Cell 122:723-734. https://doi.org/10.1016/j. cell.2005.06.021

Publisher's Note Springer Nature remains neutral with regard to jurisdictional claims in published maps and institutional affiliations. 